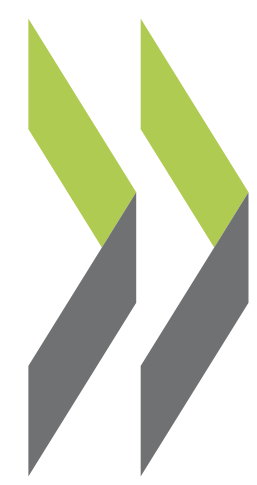

OECD Economics Department Working Papers No. 105

\title{
Savings Trends \\ and Measurement Issues
}

\section{Jørgen Elmeskov, Jeffrey Shafer, Warren Tease}


GENERAL DISTRIBUTION

OCDE/GD (91) 148

0GDES

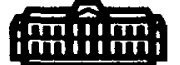

(0ECD

ECONOMICS AND STATISTICS DEPARTMENT

WORKING PAPERS

$N^{\circ} \mathbf{1 0 5}$

\section{SAVINGS TRENDS AND MEASUREMENT ISSUES}

by

Jorgen Elmeskov, Jeffrey Shafer and Warren Tease

Policy Studies Branch

ORGANISATION FOR ECONOMIC CO-OPERATION AND DEVELOPMENT

Paris 1991 
GENERAL DISTRIBUTION

OCDE/GD ( 91$) 148$

\author{
ECONOMICS AND STATISTICS DEPARTMENT \\ WORKING PAPERS \\ No. 105
}

SAVINGS TRENDS AND MEASUREMENT ISSUES

by

Jorgen Elmeskov, Jeffrey Shafer and Warren Tease Policy Studies Branch

ORGANTSATION FOR ECONOMIC CO-OPERATION AND DEVELOPMENT

Paris 1991

36030

FOR TECHNICAL REASONS, THIS DOCUMENT IS NOT AVAILABLE ON OLIS 
This paper is a slightly revised version of a paper presented to a conference on "Saving behaviour: theory, international evidence and policy implications", arranged by the Finnish Savings Banks Research Foundation and held in Helsinki, May 26-29, 1991. The paper draws on a number of previous papers concerned with saving and, as such, represents the work of a number of colleagues in the Economics and Statistics Department. In particular, thanks are due to Derek Blades and Andrew Dean, who provided helpful comments to an earlier draft. Efficient statistical assistance was provided by Anick Bouchouchi-Lotrous and Martine Levasseur and technical assistance by Sheena Bohan, Lyn Louichaoui. Terri Meehan and Pat Tuveri. The responsibility for all remaining errors rests with the authors. The views expressed are theirs and not necessarily those of the OECD nor the governments of its member countries. 


\title{
ECONOMICS AND STATISTICS DEPARTYENT
}

\section{WORRING PAPERS}

\begin{abstract}
This series of Working Papers is designed to make available, to a wider readership, selected studies which the Department has prepared for use within OECD. Authorship is generally collective, but main individual authors are named.

Comment on the Papers is invited, and may be sent to OECD, Department of Economics and Statistics, 2 rue André Pascal, 75775 Paris Cedex 16. France. Additional copies of the Papers on a limited basis can be forwarded on request.
\end{abstract}

ORGANISATION FOR ECONOMIC CO-OPERATION AND DEVELOPMENT

Copyright OECD, 1991 
Saving has attracted increasing attention in recent years. Research has focused on questions about its adequacy, determinants and measurement. This paper considers the latter issue. The main trends in world-wide and OECD-area saving over the last two to three decades are reviewed. Subsequently, the appropriateness of the saving concept used in traditional national accounts is discussed. To examine the size of some of the potential problems, a number of adjustments to traditionally measured saving are made. The concluding section raises some questions about appropriate measurement of saving, saving behaviour and policy responses to perceived lack of saving.

Dans les années récentes, une attention croissante s'est portée sur le problème de l'épargne. Les recherches se sont centrées sur les questions de 1 'adéquation, des déterminants et de la mesure de l'épargne. Les principales évolutions de l'épargne au niveau mondial et dans les pays de 1'OCDE au cours des deux ou trois dernières décennies sont examinées. La pertinence du concept d'épargne utilisé en comptabilité nationale traditionnelle est ensuite discutée. Pour étudier l'importance de certains problèmes potentiels, des corrections à la mesure usuelle de l'épargne sont faites. La conclusion soulève certaines questions relatives à la mesure appropriée et au comportement de l'épargne et aux réponses de la politique économique à 1'insuffisance perçue de 1'épargne. 


\section{Contents}

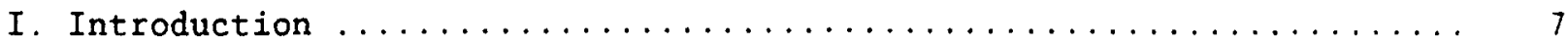

II. Broad Trends $\ldots \ldots \ldots \ldots \ldots \ldots \ldots \ldots \ldots \ldots \ldots \ldots \ldots \ldots \ldots$

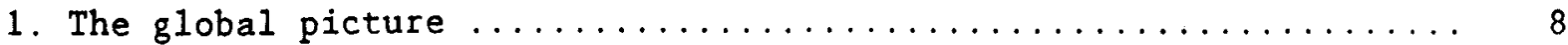

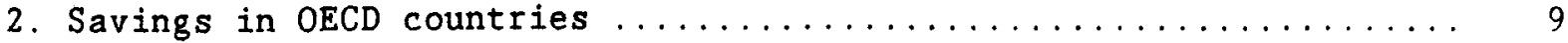

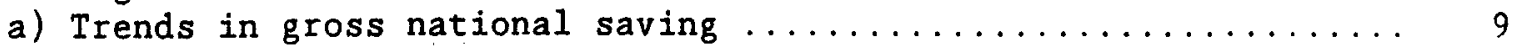

b) Sectoral components of gross national saving ............. 9

III. Adjusting National Saving and its Sectoral Distribution ......... 13

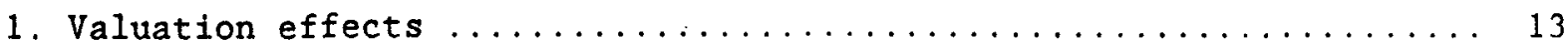

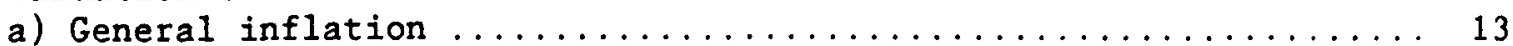

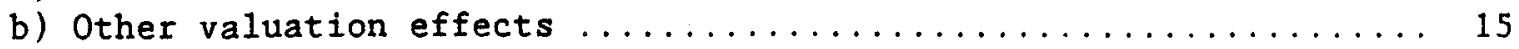

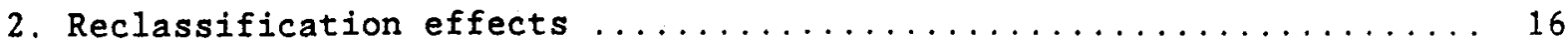

a) Reclassifications between output components $\ldots \ldots \ldots \ldots \ldots \ldots \ldots 16$

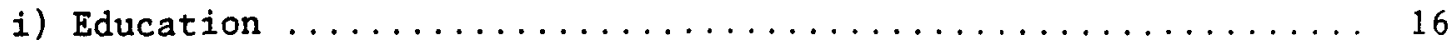

ii) Consumer durables .......................... 17

b) Reclassifications between input and output $\ldots \ldots \ldots \ldots \ldots \ldots \ldots$

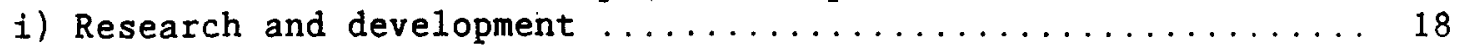

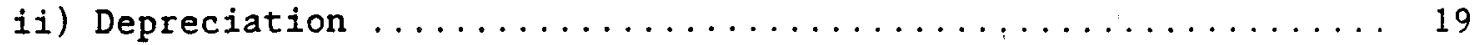

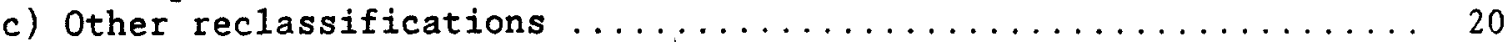

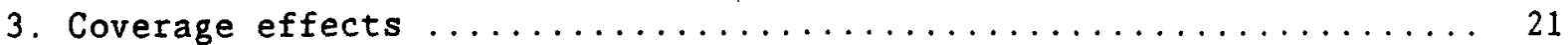

a) Household production and underground economies ............. 21

b) The depletion of natural resources and environmental

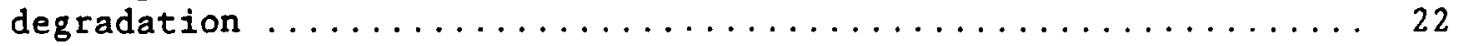

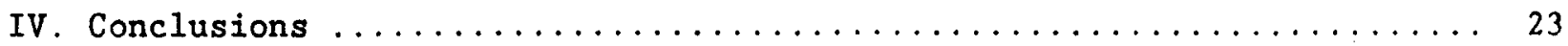

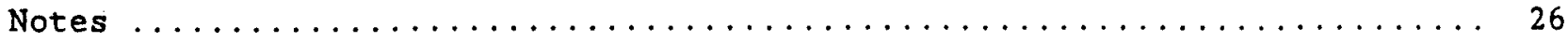

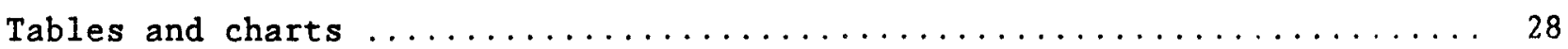

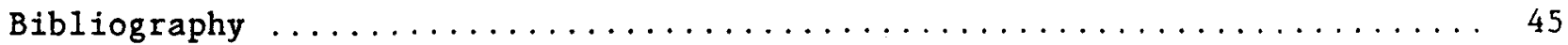





\section{Introduction}

Saving has emerged recently as a prominent policy issue in OECD countries. Concern about saving was stimulated by the possible implications of low saving rates in the 1980 s for the rate of capital formation and, in some countries, for the size of current account deficits. Persistently high real interest rates have been taken as an indicator that profitable investment is being constrained more than in the past by the flow of saving. More recently, the adequacy of saving flows globally has become an issue, with the possibility of large demands for investable funds from central and eastern European economies in transition, the prospect that economic policy reforms in at least some developing countries could make them once again importers of capital, and the likelihood that domestic investment programmes in the Asian NIEs may keep more of their saving at home. In addition, those who look only a little further ahead have raised concerns about the adequacy of saving to meet the needs of ageing populations in most OECD countries - - especially where public pension programmes have operated on a pay-as-you-go basis.

Section II of this paper examines broad trends in saving in the past thirty years, with a view to establishing stylised facts relevant to these policy issues, and to identifying, where possible, some empirical regularities that might shed light on the forces and mechanisms at work. Given the issues in the policy debate, the focus is on national saving - that is, the sum of household, business and government saving - rather than these components taken separately. Nonetheless, in joining the discussion of the adequacy of saving with research into the determinants of saving, separate influences on these components and their interdependence become relevant. Consequently, the evolution of the contributions of households, business, and government to total national saving in OECD countries is also reviewed.

Measurement issues are important where saving is concerned. Since saving is the difference between income and consumption, problems of measuring these carry over into saving. One important issue here is the definition of income - national accounts differ in important respects from the Hicksian definition of income as that which could be consumed in a given period while leaving the real value of future consumption possibilities at the end of the period the same as they were at the beginning. As regards consumption, there are other theoretical and practical measurement problems (essentially about what spending is classified as consumption, and what is investment), which potentially affect the picture of saving levels and trends. A number of measurement issues are considered in Section III to examine what difference taking them into account would make to the overall picture of levels and trends in saving in OECD countries. Section IV pulls together the broad picture that emerges from the data, taking account of the uncertainties and distortions arising from measurement problems. 


\section{Broad Trends}

\section{The global picture}

Gross saving rates for the world economy were lower in the 1980 s than earlier (1). World saving rates, as measured by conventional national accounts, fell sharply at the beginning of the $1980 \mathrm{~s}$ and were, on average, around $21 / 4$ percentage points of world GDP below their average levels of the 1970 s (Chart A). Partial data for earlier years suggest that saving rates in the 1980 s were also lower than in the 1960s. There are signs in the data for the last few years that the downward trend of world saving may have been reversed - a recovery has occurred in the OECD countries and in most non-OECD regions. With the OECD accounting for about three-quarters of world saving and investment, the broad trends in the world aggregates have been similar to those in the OECD region. Nevertheless, there have been significant changes in saving in the non-OECD region.

Taking the non-OECD countries together, saving rates have been higher than in the OECD countries since the early 1970s, and the recent recovery has been more pronounced in the non-OECD area. Saving rates at the end of the 1980 s were higher than at any point in the last 20 years.

The behaviour of saving, and also of investment, in the non-OECD region has varied considerably between country groupings, not surprisingly, given the differences in resource endowments, economic structures and stages of development among these countries. Several factors have been identified as being important in explaining differences in saving behaviour across non-OECD countries. For one, saving rates tend to, be positively related to a country's level of per capita national income, although no such pattern is visible within the generally richer and more homogeneous OECD countries. For another, saving rates seem to be related to the growth in per capita income, with higher growth associated with a higher saving rate. What conclusion to draw from this observation is not clear, however; causality between income and income growth on the one hand, and saving on the other hand, may not be unidirectional. Inflation is still another factor related to saving differences in non-OECD countries. Low inflation tends to be associated with higher saving in these countries, again a pattern not as evident within the OECD. This difference may reflect the generally less developed state of the financial systems in non-OECD countries, which allows fewer opportunities to preserve the value of savings from erosion by inflation. It is also likely that the very high inflation rates experienced in some developing countries produce reactions that are less visible within the narrower range of inflation rates observed across OECD countries $(2)$.

0il prices and production have been a major influence on aggregate non-OECD saving: the rise in saving rates through the 1970 s and the subsequent decline in the first half of the 1980 s are largely accounted for by the sharp rise and then fall in saving rates amongst the OPEC countries. Saving rates in those countries fell by around 30 percentage points of GDP in the first half of the 1980 s following the high OPEC saving of the 1970 s. Consequently, the share of OPEC saving in world saving has declined considerably. Saving rates in the dynamic Asian economies (DAEs) offset some of this as they rose by around 7 percentage points of GDP during the 1980 s to around 36 per cent in 1988 . At 
the same time, investment rates in these countries declined from their peaks of the early 1980s, leading to some large external surpluses in the second half of the 1980s. In Latin America, the onset of the debt crisis was associated with a squeeze on both investment and saving in the early 1980s, but some recovery took place towards the end of the decade.

To summarise the global picture, the major contributors to the lower world saving ratios in the early 1980 s were OECD and OPEC countries. Declines in saving in these regions more than offset a large increase in saving in the DAEs and smaller increases in the rest of Asia.

\section{Saving in OECD countries}

\section{a) Trends in gross national saving}

Gross national saving ratios have differed considerably across OECD countries. In high-saving countries, such as Japan, saving is around 30 per cent of GNP while in low-saving countries, such as the United Kingdom, Belgium and Denmark, the saving rate is about 15 per cent. Countries with higher saving rates have also had higher investment rates, and conversely for low saving countries. There has been little tendency for the dispersion in saving and investment rates across countries to decline over time. However, the correlation between saving and investment rates within countries has declined, as reflected in the large current account imbalances recorded in many countries in the 1980s (3).

Despite substantial differences in levels of saving rates, broad movements in saving have been remarkably similar across countries. Most countries experienced lower saving rates, on average, in the 1980 s than in the $1960 \mathrm{~s}$ or $1970 \mathrm{~s}$. For the OECD region as a whole, the ratio of gross national saving to GNP in the $1980 \mathrm{~s}$ was, on average, around 3 percentage points below that of the $1960 \mathrm{~s}$ and $1970 \mathrm{~s}$. In recent years there has been some recovery in the saving ratio, but it remains below the levels of the two previous decades (Chart $B$ and Table 1). Declines in average national saving rates from the 1960 s to the 1980 s in excess of four percentage points of GNP were not uncommon (Germany, France, Italy, Australia, Belgium, Denmark, the Netherlands, Spain and Sweden). In no case did national saving increase by an appreciable amount. The OECD has moved (on national income measures) from having a surplus of savings in the 1960s - - hence, exporting capital to the rest of the world - to being a capital importer in the 1980s, as gross national investment ratios declined by only 2 to $21 / 2$ percentage points (4).

\section{b) Sectoral components of gross national saving}

An examination of the sectoral components of national saving provides some insights into what major factors underlie the trends in aggregate saving, and whether the saving behaviour of the different sectors is interdependent. (These components are measured here as ratios to GNP, not sectoral income, which in any event is not a straight-forward concept given the roles of households as the owners of private business, and as taxpayers who provide the resources of governments.) 
Government Saving. The most widespread, and in most countries the largest, decline in saving from the 1960 s to the 1980 s occurred in the government sector (Table 1 and Chart $C$ ). There has been a decline in government saving in every OECD country covered by data, save Norway where government revenues were boosted by offshore energy receipts.

During the 1960s, government saving made a positive contribution to aggregate saving in all OECD countries shown in Table 1 . In many cases, government saving was in excess of 5 per cent of GNP. During the 1970s, government saving fell. Revenue growth slowed with the slowdown in activity following the first oil shock. At the same time, expenditures grew relative to GNP as social programmes continued to expand and their costs rose owing to higher unemployment. The decline in government saving was not matched by a comparable decline in capital outlays of the government sector, so that large fiscal deficits emerged in a number of countries. As government indebtedness built up and interest rates rose, the growing weight of debt interest payments in expenditures contributed further to government deficits and dissaving. Government saving fell again in the early to mid 1980s, so that many governments became dissavers in the 1980 s.

For many countries, the fall in government saving accounts for most of the decline in gross national saving. The main factor behind the recovery of saving ratios over the past few years has been a turnaround in government saving. Germany is an exception - a pickup of private saving was largely responsible for the rise in German national saving in the period prior to reunification.

The extent to which government saving affects national saving depends on the response of the private sector. If consumers anticipate the future implications of current government deficits and investment, lower government saving may be offset by additional private saving. In this case, changes in government saving may not alter national saving. The data in Chart $C$ do not suggest such a close offsetting relationship between private and public saving. however. In most cases there does not seem to have been a rise in private-sector saving in response to lower government saving. Indeed, in Japan, France and (until recently) Germany both private and public saving have been declining. The data for Canada and the United Kingdom seem to be a little more supportive of the existence of an offset, with lower government saving being associated with higher private saving. The more formal empirical evidence on this point yields mixed results, but does not support a one-for-one offset of private saving for public saving (5).

Private saving is the main source of financing for investment. Both the household sector and the corporate sector contribute substantially to the flow of private sector saving (Table 1 and Chart D). Rates of private sector saving have been relatively stable over time. In many countries, the average ratio of gross private saving to GNP in the 1980 s were little different from the averages for the $1960 \mathrm{~s}$. However, private saving ratios declined in a number of countries during the latter half of the 1980s. In most cases this decline was concentrated in the household sector.

Household saving rates (again, the ratio of sectoral saving to GNP, not to sectoral income) vary widely across OECD countries, and by much more than they vary from decade to decade for a given country. Gross household saving in 
Italy has exceeded 18 per cent of GNP in the past two decades, in Japan it has been in the neighbourhood of 15 per cent, while in the United Kingdom and Austria it has barely exceeded 8 per cent. These differences partly reflect measurement difficulties in allocating income across sectors in the economy, and partly the role of corporate saving in providing for future consumption by household owners of corporate equity. (These are discussed below). But differences in household saving rates account for from 40 per cent to 70 per cent of the variation of decade-average national saving rates across the fourteen OECD countries for which complete data are shown in Table 1.

Swings in gross household saving ratios over time are more notable than those for total private saving, the broad pattern being similar across most countries. Household saving generally increased sharply in the 1970 s before falling during the 1980s. A number of factors may have contributed to these swings, including the economic uncertainty and inflation of the 1970 s followed by the disinflation and economic recovery in the $1980 \mathrm{~s}$. In many cases, gross household saving ratios are at present little different from the rates that prevailed in the 1960s. In some cases (Japan, Germany, Canada and Greece) they are higher.

Financial market liberalisation may have contributed to the decline in household saving in some countries during the 1980s. A rapid build-up of gross personal debt occurred in the latter part of the $1980 \mathrm{~s}$ in the United States, France, the United Kingdom, Australia, Sweden, Finland and Norway as consumer credit became more readily available and new forms of debt were developed in more competitive and less regulated markets. Tax systems of some countries distorted incentives in favour of borrowing, thereby providing additional impetus to a build-up of household debt once constraints were relaxed. As additional demand pushed up asset prices (and consequently wealth), households were able to borrow still more, and they were further induced to save less. This process may have run its course. The rise in asset prices has ceased, or is even being reversed, so that both the incentive to borrow in order to buy assets such as housing and the value of current asset holdings as collateral have diminished. Income growth has also slowed considerably, especially in the countries where household debt accumulation has been important, limiting the capacity of individuals to carry higher debt burdens. Finally, there are indications that the lending criteria of financial intermediaries may have tightened after a period of laxity, as strains in borrowers' capacity to service debts has appeared. If there has been such a tightening, it would have further limited new borrowing. These factors help to explain why the decline in household saving has reversed in some countries (6).

Corporate saving provides about half of gross private saving in most countries. This saving is closely linked to corporate profits - - differing largely by the amount of dividends paid to shareholders. With the latter being relatively stable, movements in corporate saving tend to follow profit developments. A reduction in profit shares and rates of return in the 1970 s was reflected in a decline in the rate of corporate saving in most countries. The reduction in corporate saving was marked in Japan and Germany. Corporate saving has risen during the $1980 \mathrm{~s}$ with the recovery in profit shares of national income.

The saving rate for the private sector as a whole has been more stable than its household and corporate saving components: there is a relatively 
strong offsetting relationship between household and corporate saving visible in Table 1 and Chart $D$. In several cases, this relationship seems to be strongest at high frequencies (Japan and Canada). In these countries, the relationship over longer periods of time is not as strong, as evidenced by trends in aggregate private saving. By contrast, medium-term swings in household and business saving are largely offsetting in the United States and Germany, leaving the aggregate private saving ratio relatively stable.

It seems reasonable to attribute the negative relationship between components of private saving, at least partly, to households' seeing through the corporate veil. For example, in periods of strong corporate profitability, market valuations rise, thereby boosting the wealth of the household sector and reducing the need for households to save in order to fulfil future consumption plans. The evidence from various studies on data for the United States suggests that households partially pierce the corporate veil, implying that the offset between corporate and household saving is less than one (Poterba, 1987; Schultze, 1988). A lower correlation might be expected for small, financially open economies, where domestic residents hold claims in foreign firms, and much of the equity of domestic firms is held by foreigners (Dean et al., 1990). But even for a closed economy, a fully transparent corporate veil would not necessarily imply a correlation coefficient of one. Most consumption theories predict that a high proportion of temporary income fluctuations are saved, hence fluctuations in saving by corporations associated with transitory profit changes would not be offset by households.

In addition to this behavioural explanation for negative correlations of household saving with business saving, there are good reasons to believe that measurement problems play a role. Sectoral measures of saving are distorted in times of inflation. The household sector is a net holder of corporate debt. With inflation, the household sector incurs capital losses on these holdings (correspondingly, the corporate sector incurs capital gains). These are not measured in the national accounts, and therefore the income and saving of the household sector is overstated during periods of inflation, while that of the corporate sector is understated by an equal amount. Such offsetting measurement errors are a source of negative correlation between household and corporate saving, whether or not there is a behavioural relationship. Furthermore, Edey and Britten-Jones (1990) suggest that the dividing line between the household and corporate sectors in the national accounts is somewhat arbitrary because the corporate sector includes family businesses if they are incorporated, while the household sector includes unincorporated enterprises that may be distinct entities.

Before turning to conceptual measurement issues, a note of caution may be warranted concerning the broad patterns in the System of National Accounts (SNA) data. Saving, at the national level and at the sectoral level, is defined in the SNA as current receipts less current disbursements. Saving is therefore a residual and will be affected by errors in the measurement of either receipts or disbursements. Blades(1983) has noted that relatively minor errors in either receipts or disbursements can result in large errors in the residually measured saving and suggests that little significance should be attached to small differences (of 2 to 3 percentage points of GNP) in saving measures over time or across countries. 


\section{Adjusting National Saving and Its Sectoral Distribution}

The gross saving data from national accounts do not correspond very closely to concepts of saving that appear in economic theory. Numerous adjustments have been suggested to bring measured saving closer to theoretical concepts. Particularly for the United States, a multitude of alternative saving measures have been put forward, implying anything from a saving rate of near zero to a four-fold multiplication of the official measure (7). Two different purposes of adjustments may be distinguished. First, to adjust income so that it corresponds more closely to the Hicksian concept -- the maximum value a person (or sector or country) can consume during a given period and still expect to be as well off at the end of the period as at the beginning. Second, to reallocate spending between consumption and investment (implying a corresponding saving flow) so as to better reflect the use of goods and services for present benefit versus their use to meet future wants.

This section discusses a number of adjustments and attempts to classify them within a common conceptual framework. In doing so. some evidence on a few adjustments is given for a number of OECD countries. The taxonomy used in discussing various adjustments is inspired by Eisner (1988). Three kinds of adjustment to traditionally measured national-accounts concepts are distinguished. First, changes in real asset values may call for adjustments to income as measured in national accounts second, the classification of economic activities is problematic in a number of respects. Some issues have implications primarily for the definition of income, with investment or consumption correspondingly affected. Others pertain to the allocation of output and income to investment and saving as opposed to current consumption. Third, a number of activities are not covered by national accounts even though they generate income and welfare or affect future income and welfare.

\section{Valuation effects}

Valuation effects arise when changes in prices of real and financia: assets relative to consumption goods alter the real value of wealth. with changes in relative prices, the development of net wealth over time no longer reflects only the difference between current income and current consumption. An economic unit owning an asset with an increasing relative price can consume all of current income in a given period and still be better off at the end of the period than at the beginning. Thus, income in the Hicksian sense is higher than current income as conventionally measured in the face of a favourable shift in relative prices of assets.

\section{a) General inflation}

In the case of general inflation, there is a change in the relative price of financial assets in terms of a basket of goods (unless their principal value is indexed). Financial asset holders must consider a part of the nominal interest earned on financial assets as compensation for the loss in the real value of their assets. In the national accounts. nominal interest payments are included fully as a component of current income, but the erosion of the real value of financial assets and gains on debt are not accounted for. Consequently, the current income of financial asset holders will exceed Hicksian income (and conversely for debtors). When there is persistent 
inflation, these gains and losses on financial assets become predictable and it may be argued that they should be included in measures of income and saving (Hill, 1984; Blades, 1989 and Dean et al. 1990).

For a country with a limited net foreign debt position. such an adjustment will not affect the aggregate saving ratio, but it will affect the sectoral composition of saving. Specifically, in many countries the private sector is a net holder of government financial liabilities. In this case, traditional measures will overstate private sector income and saving, while understating government income and saving. (Conversely, in those countries where the government sector is a net creditor, private sector saving will be understated during periods of inflation.)

To illustrate the potential size of these effects, estimates of private saving, adjusted for inflation-induced gains and losses on net holdings of government debt, have been calculated for a number of countries. To make this adjustment, the imputed reallocation between the public and private sector of inflation gains and losses has been applied to national accounts measures of private income and saving. The adjustment for inflation is calculated by multiplying the current rate of inflation by the preceding period's stock of net domestic government liabilities held by the domestic private sector (the stock of net government liabilities less the share held by foreigners) (8). Therefore, the behaviour of the adjusted series vis-a-vis the unadjusted series will depend upon developments in inflation and in the stock of net government financial liabilities. The adjusted and unadjusted measures are shown in Chart $E$ and Table 2 .

In each case, the inflation adjustment alters the level of the private saving ratio (in some cases substantially); and in some countries the trend in private saving is also changed significantly. The effects are largest in those countries (the United Kingdom, Italy, Belgium and Greece) that have had both large stocks of government debt and large changes in inflation. In some cases, the adjusted saving series was up to 10 percentage points of GDP below the traditionally measured series. With the high inflation of the early and late 1970 s, adjusted private saving was substantially lower than measured saving in the United Kingdom and Italy. Furthermore, after adjusting for inflation, private saving rates are shown to have increased through the $1980 \mathrm{~s}$ in Italy (and in the first half of the decade in the United Kingdom), unlike the unadjusted series. This is due to the deceleration of inflation through the decade and the consequent reduction in the mismeasurement. A similar phenomena is evident in Belgium.

In most cases, however, adjustment does not alter the picture greatly. The trends are similar in both measures. In some countries (Japan, western Germany and Denmark) the government switched from being a net creditor to a net debtor in about the mid to late 1970s. In those countries, the main effect of the adjustment is to slightly accentuate the decline in the private saving ratios in those countries. This is because there was an implicit income transfer from the public to the private sector in the early period. and private saving was thus understated. When the governments became net debtors, the opposite occurred. The transfer was very small in the late 1980 s in Japan and western Germany because of low inflation. 
Similar mismeasurement may occur in the allocation of income and saving between the household and corporate sectors associated with inflation. This was mentioned earlier as a factor contributing to a negative relationship between these components of saving. In addition, any inflation component in the return on the net position of the private sector vis-a-vis the foreign sector leads to distortions of private saving and total saving. Unfortunately, the data are not readily available to allow adjustments for these distortions. But in a number of countries adjustments between the household and business sectors would alter the sectoral picture given by the national accounts data by more than adjustments between the government and private sectors, since enterprise sectors are often much larger net debtors than governments. This is one reason, in addition to the force of arguments concerning the inter-related nature of business and household saving decisions, for focusing on total private saving rather than on its separate components.

\section{b) Other valuation effects}

For a relative-price change to result in a significant deviation between Hicksian and current income, the good in question must be a significant store of wealth. At the individual level, this leaves many relative prices to watch. However, at a sectoral or national level, fewer relative-price changes are likely to be important. In any event, the literature has largely confined itself to considering house prices and equity prices.

Among other explanations offered for the decline of household saving in many countries during the $1980 \mathrm{~s}$, is increased wealth arising from capital gains on shares and fixed property (9). The argument is that households realised that Hicksian income exceeded current income, and consequently reduced saving out of current income. To the extent rising share prices reflect corporate saving. this is just another way of stating that households see through the corporate veil. Saving in the corporate sector is used to finance investment which will enhance national wealth (domestic real capital and net foreign assets) and. thus, future income. Consumers, by reducing the traditionally-measured household saving ratio, would adjust consumption correspondingly to expectations of higher future income.

Capital gains on fixed property (and capital gains on shares other than those related to corporate saving) do not represent saving with a counterpart in the accumulation of investment goods or foreign assets. They may nevertheless reflect expectations of higher future real income flows owing to improved terms of trade or higher productivity (this seems more realistic for equity prices than for housing). Such gains allow higher consumption (that is, they represent income in the Hicksian sense) and they are therefore likely to affect household saving in much the same way as corporate saving. Other reasons for asset price changes would suggest a smaller effect, on household saving. For example, changes in the rate at which future returns are discounted affect prices of assets without altering the future stream of consumption that can be maintained. Also, higher house prices reflecting higher implicit rental costs of housing leave households with no scope to increase consumption of other goods, except by annsuming less housing. Hence the household sector as a whole may not feel much better off from such capital gains (10). In addition, unlike capital gains reflecting corporate saving, and possible trend real gains on fixed property reflecting secularly increasing 
scarcity of desirable land, other types of capital gains on equity and fixed property suffer a high risk of being reversed.

As discussed in Blades (1989), revaluation issues were reviewed in connection with the upcoming revision of the SNA. In this connection, a distinction was made between inflation-induced holding gains and 1osses, which in the context of persistent inflation are to some extent predictable, and other holding gains and losses which are generally unexpected. While the former may be assumed to strongly affect consumption behaviour, and thus present a case for being included in income, the impact of the latter on consumption was regarded as uncertain and a change in the SNA to include such gains was therefore ruled out. Also in the context of extended national accounts, doubts have been expressed about the inclusion of such holding gains and losses (Eisner, 1988).

\section{Reclassification effects}

In setting up the system of national accounts, choices have to be made abcut the classification of which activities contribute to final output and income and which activities contribute to production and income as intermediate inputs. The boundary between intermediate inputs and output is sometimes difficult to draw, and it can have a significant effect on the picture of saving A prime example of some of the uncertainties in this domain is the classification of research and development (R\&D) expenditure, which is treated as an intermediate input rather than a final output that adds to the stock of intangible capital. A second important example is the treatment of a number of public services as final outputs rather than intermediate inputs in the production of goods and services of ultimate utility. Another choice arises in deciding what outputs to classify as investment and what as consumption. This choice is not always clear, with education expenditure and household purchases of durable consumer goods being important examples Where the lines are drawn between investment and consumption affects saving measures.

\section{a) Reclassifications between output components}

\section{i) Education}

Education is regarded as consumption in the SNA, but it is clear that education contains an aspect of investment in human capital with an economic return. The importance of this aspect varies between different types of education. It may be regarded as being strongest in education qualifying for specific occupations, whereas broader types of education, such as primary education, aim at least partly to fulfil some wider social goals and ought not be thought of as investment having a specific economic return. Unfortunately, available statistics do not allow educational expenditure with a strong investment aspect to be clearly distinguished from other. Also. private sector expenditure on education was not available for the adjustments shown below. This is a source of bias in the adjusted figures and calls for a warning about making comparisons across countries since private spending on education varies significantly. 
Table 3 shows national gross saving ratios adjusted for, respectively, public expenditure on higher education and education in general. The first might be seen as having a strong investment aspect, whereas total education expenditure comprises both consumption and investment aspects (11). Figures are available only from 1970. Typically, the adjustment for public expenditure on higher education add between $1 / 2$ and 2 percentage points to the national saving ratio. Among the outliers are Canada and the Netherlands with rather high expenditure and Italy, Japan and France with low public expenditure on higher education. Adding in higher education does not change the trend of saving significantly, with Denmark as the country where the adjustment gives rise to the largest change of trend (a downward correction).

Treating tótal public expenditure on education as gross saving gives rise to a significant upward adjustment of saving ratios. In all other countries than Greece, Portugal, Italy, United States and Germany the adjustment exceeds 5 percentage points. Needless to say, the size of the adjustment depends on both expenditure per pupil and the demographic make-up of the population. The countries are split rather evenly into groups where the adjustment affects the trend of saving negatively or positively. The largest adjustments of the trend are found in Denmark (negative) and Ireland (positive).

A much wider issue, which rightly belongs under the heading of coverage below, is whether public expenditure on education is the right kind of measure of the investment in human capital. First, as in other fields concerning public expenditure, it evaluates investment on a cost basis, with no market test of value. The change in discounted future value of lifetime income of the population would be a more appropriate measure. Secondly, even with these cost measures the opportunity costs of not working while engaged as a student or trainee -. a significant portion of the cost of post secondary education - - are ignored.

\section{ii) Consumer durables}

Purchases of consumer durables are treated differently in the system of national accounts depending on the purchaser. If a firm purchases a durable good in order to sell its services to consumers the transaction is regarded as a business investment. The future revenue from selling the services is added to future gross income and production. Consumers buying a durable in order to enjoy its services are recorded as consuming the full amount of the purchase in the period where it is taking place. The question may be raised as to why a purchase of a consumer durable should be considered less of an investment when it is made by a household than when it is made by a firm.

Table 4 presents adjusted national gross saving ratios, treating household purchases of consumer durables as investment. Two simplifying assumptions have been made in order to facilitate the adjustment - in both cases concerning the adjustment to income to take into account the services flowing from the stock of consumer durables. This adjustment to income consists of two parts, one reflecting depreciation of the assets and one reflecting their net return. The former is in each year assumed to equal the new purchases of consumer durables, corresponding to an assumption of a constant stock of consumer durables, and the second is assumed to be zero (12). These approximations are rough and ready, but they affect only the denominator 
of the saving rate (gross expenditures on durables are treated as investment in the numerator) and, as such, they introduce relatively little bias.

In most countries, the adjustment adds about $4-5$ percentage points to the gross national saving ratio. The effect is somewhat larger in Canada and relatively small for Japan. In most cases where data permit a comparison between the 1980s and earlier decades, there is some evidence that the fall in the saving rate is slightly attenuated by adjusting for purchases of consumer durables.

What one makes of this adjustment depends very much on the purpose at hand. If it is to evaluate theories of saving behaviour over the relatively short run, the distinction is crucial between, on the one hand, spending on services and goods that provide only immediate benefits and, on the other hand, spending on durable goods that provide services over an extended period of time. If, instead, interest is focused on the flow of funds available for business investment, whether consumers spend on durables or non-durables is of no consequence. The distinction is of only limited importance when looking at household behaviour over the medium-to-long term, when depreciation and scrapping follow expenditures on durable goods, leaving additions to durable stocks very small relative to gross expenditures.

\section{b) Reclassifications between input and output}

\section{i) Research and development}

In the present version of SNA, $R \& D$ is treated differently depending on the sector undertaking the activity and the character of activity. Thus, R\&D undertaken in the public sector is treated as consumption while business R\&D is treated as an intermediate input and not counted directly in final output. The result is that current business expenditures on R\&D are treated as a cost of production. To the extent output prices are raised correspondingly, $R \& D$ contributes to GDP and indirectly adds to consumption or investment depending on whether it is undertaken in the consumption or investment goods sectors. However, current R\&D expenditure that is not reflected in output prices gets counted neither in GDP nor saving. At the same time, creating facilities for undertaking $R \& D$, i.e. building the necessary infrastructure, is treated as investment.

Treating business $R \& D$ as an intermediate input is unsatisfactory both because it has little impact on final production in the current period, and because the decision to undertake R\&D in many cases resembles a decision to undertake a traditional investment. In a saving context, a firm which has made an $R \& D$ expenditure may pay out all of traditionally defined income to its owners and yet be worth more to them at the end of a period.

The practice of recording public sector $R \& D$ as public consumption can be defended on the grounds that it has not been subject to the same kind of investment calculus as business $R \& D$ (much of it is pure research) and, therefore, should not be treated as investment. However, this argument has not been applied to public investment in, for example, roads and bridges, which are 
treated as investment in the SNA, and, moreover, some public R\&D may in fact have a high economic return.

Military R\&D is undertaken both in the business sector (with public-sector funding) and in the public sector (13). In both cases, it is not directly aimed at civilian goods enhancing future production capacity and should, therefore, not be counted as business investment. However, in practice, insights based on $R \& D$ may be fungible, and some military $R \& D$ therefore may enlarge future production possibilities.

Table 5 presents gross national saving rates adjusted for, respectively, business-sector and total-economy $R \& D$ expenditure (14). In neither case have attempts been made to exclude military R\&D (15). Adding business R\&D expenditure to both national saving and to GNP is based on the implicit assumption that output prices are not adjusted to take into account the current costs of $R \& D$ and may, thus, be said to represent an extreme alternative to the conventional treatment. Under this assumption, the adjustment only slightly increases the saving ratio over the last three decades - - most notably in the United States, Germany, Japan and United Kingdom. The trend of the saving ratio is also slightly modified, since business $R \& D$ has been rising relative to GNP in virtually all countries. The rise appears to have been particularly pronounced in Sweden, Japan, Germany and Finland. In contrast, business R\&D grew only slowly in the United States and Australia. It should be noted, however, that the adjustment for the $1960 \mathrm{~s}$ in some cases is based on very few observations of $R \& D$ expenditure.

Adjusting gross saving for total-economy rather than just business R\&D raises saving ratios somewhat further; and in most countries makes a further positive contribution to the trend of the saving ratio. Total R\&D activity during the 1980s was highest in the United States. Sweden, Germany and Japan. The positive impact on the trend of the saving ratio was particularly pronounced in the same countries as for business R\&D, i.e. Sweden, Japan, Germany and Finland.

\section{ii) Depreciation}

So far the adjustments to SNA saving that have been considered would overwhelmingly result in higher measures of saving or unchanged aggregate measures, although trends in savings, cross-country comparisons and sectoral allocations are altered in different ways. Depreciation is one of several considerations that suggest much lower saving rates but again with a range of implications for trends and comparisons.

A net income and net saving measure is called for by the Hicksian definition of income. Switching from considering gross to net saving amounts to re-classifying part of investment as intermediate input. Saving and income are reduced accordingly. Unfortunately, measurement problems are very large in connection with depreciation, affecting comparisons across countries and trends as well as levels. This is one reason why the discussion has been framed in terms of gross saving. Among the factors which affect cross-country comparisons are the price level at which depreciation is measured (historical or replacement costs), assumptions about service lives and the shape of 
survival functions. Over time, questions may be raised as to the degree of adjustment to service lives and survival functions.

Bearing these caveats in mind, Table 6 presents data on both net and gross national saving ratios for the major seven OECD countries. Two conclusions stand out: net saving ratios are significantly smaller than gross ratios and they have fallen more than gross ratios over the last decades. The relative increase in depreciation over time is related to a shift in the composition of investment towards components with shorter service lives, with changes in service lives for individual components playing less of a role (16). Evidence on the capital intensity of production in the business sector suggest that, in a number of countries, there has been a trend substitution towards capital which may go some way towards explaining increased importance of depreciation. This tendency was much weaker in the $1980 \mathrm{~s}$ than in earlier decades, however.

The adjustments to gross saving rates discussed above would also affect investment and, thus, depreciation and net saving rates. However, the related depreciation would modify the various adjustments to very different extents. Consumer durables, which generally have relatively short service lives, lie near one end of the spectrum. For those, as already noted, taking account of depreciation would cancel out most of the gross adjustment, on average, and the trend of net saving would be left roughly unchanged from one measured without taking durables into account. The other extreme may be adjustment to take into account investment in education. A substantial part of investment in education may not be depreciated before the persons in question withdraw from the labour market. In this case trends of net saving before and after adjustment may deviate significantly -- in particular if demographic developments are uneven or if educational efforts per pupil vary.

\section{c) Other reclassifications}

Other activities, resembling business-sector $R \& D$, should arguably be re-classified from intermediate input to output. Among these are raw-material prospecting and training provided in the work-place. Doing so would raise estimates of income and saving - again this adjustment would rest on the assumption that prices of current output have not been raised to take into account the costs of such intermediate inputs but rather that the latter are incurred out of profits to be recuperated in the future. However, there are other candidates for re-classification, which would affect estimates of the saving ratios negatively by raising measured income, without raising measured saving. Since gross saving only accounts for about a third to a fifth of traditional GNP, reclassifications affecting only the denominator of the saving ratio would have to be important if the saving ratio should be significantly affected.

The question has been raised whether a range of, in particular public, services currently treated as consumption, are not in fact intermediate input. Thus, military and police services may not be regarded as final output in themselves but rather as means to the orderly production of other final outputs (see e.g. Eisner, 1988). Similarly, certain health expenditures, e.g. related to work injuries, may have a character which is closer to intermediate input than final consumption. Also public activities to offset the environmental 
impact of production may be in this category. Such reclassifications would reduce real income without affecting saving and, thus, raise the saving ratios. The difficulty with this argument is that factor incomes (wages) are obviously being generated in producing these services. For the argument to be valid, transferring these functions from the public to the private sector, where they would be appropriately recorded as intermediate input, should lead to a fall in GDP. This would only be so if prices did not react to the increased costs. Taking into account effects operating via taxes, which could be cut in the case of such a transfer, the argument may seem less extreme.

There are also expenditures whose status as investment in the SNA could be reconsidered. The question was raised earlier of whether public investment, which is usually not subjected to the same investment criteria as business investment, should be excluded from investment, with a consequent downward adjustment of saving. The U.S. National Income and Product Accounts, in contrast to SNA, follow this approach and treat public investment as part of public consumption. Examples of questionable investment also arise in the private sector. The SNA treats household purchases of cars as private consumption, while the company car put at disposal to the employee is treated as an investment. While a case may be made that all car purchases should be treated as investment, as discussed above, if it is nevertheless decided to treat the purchase of a household car as consumption then the same principle should be applied to the company car provided for private use.

\section{Coverage effects}

Many areas related to economic activity are not recorded in the national accounts. With a few exceptions, SNA records activities that involve exchanges in a market - e either factor markets or output markets or both. However, many unrecorded activities also have effects on material well-being, which may be compared to those arising from goods and services sold on a market.

\section{a) Household production and underground econonies}

Among the activities which are not counted in the standard national accounts, because they do not produce products sold in markets nor is their production remunerated by payment of factor incomes, is household work; but it does contribute to consumption. Being to a large extent of a services nature and hence not storable, the omission of household activity may not greatly affect measures of saving (17). However, household work may considerably affect the estimate of income and, thus, the denominator of the saving ratio (18). For the United States, estimates of the value of household work have been in the range 25-50 per cent of GDP (Murphy, 1982). Whatever value is assumed, it is perhaps the extent to which its trend deviates from the trend of other income that matters, as this will affect the trend of the saving ratio. Labour force participation rates have been rising in most OECD countries, suggesting that household work may have grown less than registered income, thus indicating that if saving ratios were adjusted for household production they might be shown to have fallen less than indicated by SNA measures. On the other hand, rising capital intensity of household work may have boosted productivity in this 
sector enough to match growth of registered income. Here we come back once again to the question of the treatment of durable goods.

The so-called black or underground economy comprises many different activities - - some criminal, some evasive of taxes or civil economic regulation, and some merely informal - . that by their nature are unregistered. Estimates of the magnitudes involved have varied considerably for individual countries, depending on the methods used, as well as across countries (Frey and Weck-Hanneman, 1984). In consequence, it is difficult to say how these activities affect saving ratios. Certainly adjusted figures would have higher income in the denominator. However, it is unclear whether saving out of this income that is directly reinvested in these activities or otherwise goes unrecorded is a smaller or larger share of the numerator.

\section{b) The depletion of natural resources and environmental degradation}

Natural resource use should, in principle, be considered in assessing saving, but it is not reflected in the usual saving measures. Natural resources are in many ways comparable to a capital stock and have been treated as such in the literature (e.g. Solow, 1986). The discussion of sustainable development in the wake of the Brundtland report has also led increasingly to regarding the state of the environment as a capital stock (e.g. Nicolaisen, Dean and Höller, 1991). Given this view, the Hicksian income concept, insisting on unchanged real net worth, will be affected by changes in the stocks of natural-resource or environmental capital (19).

The theoretically appropriate corrections of net national income, and thus net saving, have been derived from the Hamiltonian expression and first order conditions commonly used in intertemporal maximisation (Hartwick, 1990). In the case of non-renewable natural resources used in production, net income as normally defined should be reduced by the rents on the reduction in the stocks of these resources. This is the price less the marginal cost of extraction (assuming that the price properly reflects its marginal contribution to output). Making such an adjustment will lower NNP and net saving measures for a country running down its resource stocks. In most OECD countries such considerations may not be of first-order importance, but they are worth keeping in mind when assessing, for example, the high Norwegian saving ratio as conventionally measured or, perhaps more critically, the low saving ratio in the United Kingdom. Obviously, this issue is all important for Middle Eastern oil producers.

Renewable natural resources are important in a number of countries. Among the examples of such resources are fish stocks and forests. Contrary to tendencies in other areas, where increased pressure is being put on natural resources, forest resources have increased in most OECD countries in recent years (Table 7). The rule analogous to that for non-renewable resources for adjusting standard income and saving concepts for changes in such stocks is to value them at the rent component of their value. Thus, with stocks rising, measured income and saving would be increased (barring valuation effects on the stock from relative-price shifts against timber, or relative increases in the marginal costs of harvesting, or other changes to rents). Finland is an example of a country where an already relatively high national saving ratio would have appeared higher in the 1980s, when adjusted for the increase in this 
renewable resource. However, rents on natural resources have notoriously been volatile and behaviour in response to changes in natural-resource availability is likely to share some of the characteristics of behaviour in response to valuation changes in stock markets discussed above.

Among the many difficulties in correcting saving and income measures for environmental degradation is the inappropriate or non-existing pricing of environmental "services" While both oil and wood, the examples used above. fetch a market price representing their scarcity value, this is not the case for environmental goods -. for which there is generally no ownership. Consequently, while it would clearly be appropriate to adjust national saving for changes in environmental stocks. doing so is problematic. It is not just a matter of valuing changes in stocks, if one were to adjust traditional income and saving concepts to take into account degradation of the environmental capital stock, however valued, the flows of environmental services would also need to be added into the income flow for consistency. Such adjustments would lead to lower measures of saving ratios so long as the value of the environmental capital stock were declining, since the services from the stock. as with any services, are not storable and cannot have a higher value than the stock.

\section{Conclusions}

A number of stylised facts emerge from the foregoing review of saving.

- Average saving ratios differ substantially among OECD countries (and across non-OECD areas, as well) These differences are not easily accounted for by differences in economic factors.

- Broad trends in saving are similar across OECD countries, suggesting that common factors are at work Saving rates rose generally from the $1960 \mathrm{~s}$ to the early 1970s, then were lower in the first half of the 1980 s, before recovering in recent years.

- Swings in saving of the government sector account for much of the variation over time of total saving, with little tendency for private saving to offset these swings.

- Private saving has been relatively stable as a share of GNP, with changes in household and business saving tending to cancel one another. This is consistent with the view that household saving behaviour takes business saving into account; it may also reflect variable but offsetting measurement errors in corporate and household saving.

- For some countries where household access to credit improved, a tendency for household saving to be especially weak can be discerned in the 1980s, at least until late in the decade. Very low saving rates almost certainly reflect transitional behaviour; what is not yet clear is whether saving will be affected over the longer-term future 
Even for what they purport to measure, SNA measures of saving are subject to substantial error. Not much should be made of differences across countries or over decades of even 2 or 3 per cent. Adjustments of gross saving rates on a SNA basis in order to correct for recognised conceptual deficiencies can be much larger. Although subject to very large errors and implemented only selectively, the consideration of various adjustments suggests the following:

- Most adjustments to gross saving (particularly to take account of the contributions of $R \& D$ and education to intangible capital and to treat consumer durable purchases as investment) would boost national saving ratios. Some make a large difference in relative sectoral contributions to saving with little or no effect at the national level. But deducting depreciation (which is provided by the SNA but especially poorly measured), and depletion of both resource and environmental stocks (which is not now measured) would give net saving ratios that are much lower than the SNA gross ratios, even if other adjustments were made generously

- It is difficult to draw a conclusion about saving trends, taking account of adjustments, because the errors involved are large in relation to the observable trends, and some adjustments have offsetting implications for trends. Nevertheless. the general picture of the 1980 s as a period of weak saving in the OECD area, at least until the last years of the decade, seems relatively robust.

While only impressionistic, these observations bear on the answers to three questions, one about the measurement of saving, one about how well saving behaviour is understood, and one about policy

How should saving be measured? The range of possible measures of saving leaves the overall picture clouded. There are two problems. One is that adjustments of saving measures to obtain closer correspondence with theoretical concepts come at a cost of introducing new sources of measurement error. This is no reason not to seek a more unbiased picture of overall saving levels, but it does raise questions of how far it makes sense to go in creating more elaborate measures for monitoring developments over the short to medium run. The second problem is that the most useful measure depends on the purpose at hand. For example, it seems essential to treat durable goods accumulation as saving in efforts to build and test empirical models of household saving; such adjustments are beside the point in assessing the flow of funds available to expand the business capital stock. Indeed for this purpose, one might rather adjust saving by subtracting residential and government investment from total investment. Such a focus is becoming less and less relevant. however, at least for single countries as constraints or international capital flows are removed For other specific purposes, for example, documenting the future cost of natural resource depletion or degradation, it is useful to extend measures of saving and capital to include them. But for short-run macroeconomic analysis they are not of much significance.

An effort to develop an inclusive measure of saving activity that makes provision for the future may not be worthwhile. The conceptual ambiguities and measurement problems have been illustrated. Such efforts also deflect attention from more direct evidence of how well a society is providing for the future. After all, finding that saving has been under-measured in the past 
does little or nothing to change the picture of future consumption possibilities. For a given flow of goods and services production, it simply means that the social return to saving and the productivity of capital, more inclusively defined, has been lower then suggested.by traditional measures.

Do we understand saving? The picture of saving sketched here provides some glimpses of patterns that pose challenges for theory. Other work has documented much more precisely a lack of correspondence between the data and rational, forward-looking, lifetime-consumption theories of consumer behaviour (for example, Campbell and Mankiw, 1989 and Bosworth, 1990). Liquidity constraints have been revived as a key element in consumption theory to deal with the tendency for consumption to track income relatively closely. But current theories are unsatisfactorily ad hoc, and deal with a limited range of experience. In particular, large differences in saving across countries are poorly explained. Indeed, high saving in some high growth countries (for example, Japan, Korea and Taiwan) are not easily accounted for and very low saving in some other more slowly growing countries with ageing populations (most notably, the United States) only a little easier to understand in terms of standard theories. This leaves saving, or perhaps more generally, the decision-making of individuals where intertemporal choices and uncertainty are involved, a particularly interesting area for research.

Should a decline in saving be a matter of policy concern? The evidence that saving behaviour does not correspond well with the predictions of theories that assume fully efficient intertemporal consumption planning argues against resolving this question by appealing to an a priori presumption that saving is optimal, or that it is sub-optimal only to the extent that households face identifiable distortions in making decisions about how much to save. This evidence does not, however, directly support the view that there is too little saving rather than too much. It is doubtful that even a detailed and more formal analysis of data could fully resolve this issue objectively; in the end, subjective judgements are likely to be called for.

If the conclusion is that saving ought to be higher the stylised facts developed here suggest that the policy efforts should concentrate on public finances. For one thing, this is where the decline in saving was concentrated. For another, more saving in the public sector is not likely, on the basis of observed trends, to be fully or even largely offset by private behaviour. The broad and informal review of the data presented here can be only suggestive with respect to this second point, but it is supported by the overwhelming weight of more detailed and formal statistical studies. 
1. The data used here and in the charts relate to gross national saving and investment relative to GNP for the OECD and GDP elsewhere. The data have been aggregated over six regions; OECD, OPEC, Latin America, Africa, the newly-industrialising economies of Asia and the rest of Asia. Because of the poor quality of the historical data, the Soviet Union and eastern European countries have been excluded from the analysis. The data for the non-OECD regions are taken from the World Bank World Tables 1989-90. The charts do not include data for every country in each region and are, therefore, not comprehensive measures of saving and investment in those regions. This was due to the lack of a full run of data for some countries. Those countries that did not have a full run of both saving and investment data for the full period (1970-1988) were excluded. China was an exception. An investment series was created from saving and current account data.

2. Aghevli et al. (1990), Lahiri (1989) and Otani and Villanueva (1988) discuss determinants of saving in non-OECD countries.

3. See, for example, Dean et al. (1990).

4. There is some doubt about OECD's apparent position as a capital importer, since the recent current-account deficits of the OECD region have been about the same size as the world current-account discrepancy. both running at around $\$ 100$ billion annually.

5. See, for example, Nicoletti (1988).

6. Financial liberalisation could prove to have durable effects on saving behaviour, even though transitional effects on saving levels can be expected to wear off. This depends on whether consumer borrowing is pushed to the point where liquidity constraints re-emerge as the principal regulator of spending, or whether equilibrium is established with most individuals choosing not to bring forward spending as much as they might because considerations of lifetime consumption and rates of return on saving come into play. Developments in recent years in those countries where consumer credit facilities have expanded rapidly would seem to point to a tendency to spend until liquidity becomes a factor. But experience is still relatively short, and high spending propensities could prove to be a temporary over-reaction.

7. For an overview of some alternative saving measures for the United States see Cullison (1990).

8. To the extent the domestic private sector holds foreign public debt, and the domestic government debt is held by foreigners, the adjustment is incomplete. In these cases exchange-rate adjustments are likely to play an important role. The effects will differ between countries and over time because of differences in policy with respect to borrowing in domestic or foreign currencies.

9. In the United States, real household capital gains on corporate equity have been estimated at 2.5 and 6.5 per cent of GDP in, respectively. the first and the latter half of the 1980s (Harris and Steindel, 1991)

Dean et al. (1990) quote research indicating that changes in real exchange rates may sometimes be of importance due to household ownership of assets denominated in foreign currency. 
10. This point was stressed by Harris and Steindel (1991), who also provided research showing that stock-market based estimates of corporate assets were poor at explaining future output. However, it may be noted that in some cases this may not be a relevant test. If, for example, a country experiences a terms-of-trade gain, which leads to higher stock market values in the affected sectors, the value of output or income will be higher as long as the gain is sustained. Thus, it would make sense to include such a gain in income even through no physical investment is undertaken or no foreign assets acquired.

11. It should be noted that with widely differing educational systems across countries, the classification of educations as higher or not may also be uncertain.

12. It may be argued that due to taxation on the services from durables, when sold by firms, consumers receive an incentive to boost their stock of durables to a point where the undistorted return is relatively low compared with e.g. the real rate of interest. This tendency is strengthened by taxation (and consequent tax deductibility) of interest flows.

13. The question about military R\&D touches upon a broader question about the distinction between sectoral $R \& D$ expenses and sectoral $R \& D$ effort, with military funding of part of business-sector $R \& D$ effort as an example of the distinction

14. The adjustments have been made taking the averages of whatever observations were available. Thus, for some countries decennial averages are based on a limited number of observations.

15. In the United States, about two-thirds of government R\&D appropriations have in recent years been for defence purposes. Similar ratios are for the United Kingdom about half, for France about a third and for Sweden about a quarter. In the same countries, government finance accounted for between a third (Sweden) and half (United States and France) of total R\&D.

16. See Höller (1990).

17. One of the exceptions to this rule is household construction work. Moreover, some household services may be viewed as contributing to immaterial investment, $e g$ nurturing, training and educating children.

18. For the valuation problems associated with household work see e g. Murphy (1982).

19. This discussion ignores the distinction between income and welfare. 
Table 1. Saving

(Gross saving as a ratio of GNP)

\begin{tabular}{|c|c|c|c|c|c|}
\hline & \multirow[t]{2}{*}{$1960 \mathrm{~s}$} & \multirow[t]{2}{*}{$1970 \mathrm{~s}$} & \multirow[t]{2}{*}{$1980 \mathrm{~s}$} & \multicolumn{2}{|c|}{$\begin{array}{c}\text { Change between } 1980 \mathrm{~s} \\
\text { and }\end{array}$} \\
\hline & & & & $1960 s$ & $1970 \mathrm{~s}$ \\
\hline \multicolumn{6}{|l|}{ United States } \\
\hline National & 19.7 & 19.4 & 163 & -3.4 & -3.1 \\
\hline Public & 2.0 & 0.4 & -2.1 & -4.1 & -2.5 \\
\hline Private & 17.7 & 19.1 & 185 & 0.8 & -0.6 \\
\hline Household & 9.2 & 10.7 & 9.5 & 0.3 & -12 \\
\hline Corporate & 8.5 & 8.4 & 9.0 & 0.5 & 0.6 \\
\hline \multicolumn{6}{|l|}{ Japan } \\
\hline National & 34.5 & 353 & 31.6 & -2.9 & -3.7 \\
\hline Public & 6.2 & 4.8 & 4.6 & -1.6 & -0.2 \\
\hline Private & 28.3 & 30.4 & 26.7 & -1.6 & -3.7 \\
\hline Household & 133 & 17.9 & 15.6 & 2.3 & -2.3 \\
\hline Corporate & 15.0 & 12.6 & 11.2 & -3.8 & -1.4 \\
\hline \multicolumn{6}{|l|}{ Germany } \\
\hline National & 27.3 & 24.3 & 22.5 & -4.8 & -1.8 \\
\hline Public & 6.2 & 3.9 & 2.0 & -4.2 & -19 \\
\hline Private & 21.1 & 20.4 & 20.5 & -0.6 & 0.1 \\
\hline Household & 6.9 & 8.7 & 7.8 & 0.9 & -0.9 \\
\hline Corporate & 142 & 11.8 & 12.7 & -1.5 & 0.9 \\
\hline \multicolumn{6}{|l|}{ France } \\
\hline National & 26.2 & 25.8 & 20.4 & -5.8 & -5.4 \\
\hline Public & & 3.6 & 1.3 & $\ldots$ & -2.3 \\
\hline Private & . & 22.2 & 19.0 & . & -3.2 \\
\hline Household & . & 13.6 & 10.3 & . & -3.3 \\
\hline Corporate & . & 8.6 & 8.4 & . & -0.2 \\
\hline \multicolumn{6}{|c|}{ United Kingdom } \\
\hline National & 18.4 & 17.9 & 16.6 & -1.8 & -1.3 \\
\hline Public & 3.6 & 2.6 & 0.1 & -3.5 & -2.5 \\
\hline Private & 14.8 & 15.3 & 16.6 & 1.8 & 1.3 \\
\hline Household & 5.4 & 6.1 & 6.0 & 0.6 & -0.1 \\
\hline Corporate & 9.4 & 9.2 & 10.4 & 1.0 & 1.2 \\
\hline \multicolumn{6}{|l|}{ Italy } \\
\hline National & 28.1 & 25.9 & 21.9 & -62 & -4.0 \\
\hline Public & 2.1 & -5.6 & -6.7 & -8.7 & -1.1 \\
\hline Private & 26.0 & 31.2 & 28.3 & 2.2 & -29 \\
\hline Household & $\ldots$ & 24.5 & 21.1 & . & -3.4 \\
\hline Corporate & . & 6.6 & 7.5 & & 0.9 \\
\hline \multicolumn{6}{|l|}{ Canada } \\
\hline National & 21.9 & 22.9 & 20.7 & -1.2 & -2.2 \\
\hline Public & 3.6 & 2.7 & -1.6 & -5.2 & -43 \\
\hline Private & 18.2 & 20.1 & 22.3 & 4.1 & 2.2 \\
\hline Household & $7: 8$ & 10.4 & 12.3 & 4.5 & -1.9 \\
\hline Corporate & 10.5 & 9.7 & 9.9 & .0 .6 & 0.2 \\
\hline
\end{tabular}

Source: OECD National Accounts. 
Table I (Continued)

\begin{tabular}{|c|c|c|c|c|c|}
\hline & \multirow[t]{2}{*}{$1960 \mathrm{~s}$} & \multirow[t]{2}{*}{$1970 \mathrm{~s}$} & \multirow[t]{2}{*}{$1980 s$} & \multicolumn{2}{|c|}{$\begin{array}{c}\text { Change betwoen } 1980 \mathrm{~s} \\
\text { and }\end{array}$} \\
\hline & & & & $1960 \mathrm{~s}$ & $1970 s$ \\
\hline $\begin{array}{l}\text { Austalia } \\
\text { National } \\
\text { Public } \\
\text { Private } \\
\text { Household } \\
\text { Corporate }\end{array}$ & $\begin{array}{r}24.7 \\
\ldots \\
\ldots \\
\ldots\end{array}$ & $\begin{array}{r}24.0 \\
2.9 \\
21.1 \\
13.4 \\
7.7\end{array}$ & $\begin{array}{r}20.2 \\
1.7 \\
18.3 \\
11.0 \\
7.3\end{array}$ & $\begin{array}{r}-4.5 \\
\ldots \\
\ldots \\
\ldots\end{array}$ & $\begin{array}{l}-3.8 \\
-1.2 \\
-2.8 \\
-2.4 \\
-0.4\end{array}$ \\
\hline $\begin{array}{l}\text { Austria } \\
\text { National } \\
\text { Public } \\
\text { Private } \\
\text { Household } \\
\text { Corporate }\end{array}$ & $\begin{array}{r}27.7 \\
7.2 \\
20.5 \\
5.4 \\
15.1\end{array}$ & $\begin{array}{r}28.0 \\
6.2 \\
21.8 \\
6.2 \\
15.6\end{array}$ & $\begin{array}{r}24.3 \\
2.7 \\
21.7 \\
6.5 \\
15.2\end{array}$ & $\begin{array}{r}-3.4 \\
-4.5 \\
0.9 \\
1.1 \\
0.1\end{array}$ & $\begin{array}{r}-3.7 \\
-3.5 \\
-0.1 \\
0.3 \\
-0.4\end{array}$ \\
\hline $\begin{array}{l}\text { Belgium } \\
\text { National } \\
\text { Public } \\
\text { Private } \\
\text { Household } \\
\text { Corporate }\end{array}$ & $\begin{array}{r}22.2 \\
1.2 \\
21.0 \\
9.7 \\
11.3\end{array}$ & $\begin{array}{r}22.7 \\
0.0 \\
22.7 \\
12.4 \\
10.4\end{array}$ & $\begin{array}{l}16.4 \\
-6.0 \\
21.8 \\
10.4 \\
11.4\end{array}$ & $\begin{array}{r}-5.8 \\
-7.2 \\
0.8 \\
0.7 \\
0.1\end{array}$ & $\begin{array}{r}-6.3 \\
-6.0 \\
-0.9 \\
-2.0 \\
1.0\end{array}$ \\
\hline $\begin{array}{l}\text { Denmark } \\
\text { National } \\
\text { Public } \\
\text { Prtvate } \\
\text { Bousehold } \\
\text { Corporate }\end{array}$ & $\begin{array}{r}23.3 \\
\ldots \\
\ldots \\
\ldots\end{array}$ & $\begin{array}{r}20.9 \\
6.0 \\
14.9 \\
\ldots \\
\ldots\end{array}$ & $\begin{array}{r}15.5 \\
0.4 \\
15.1 \\
\ldots \\
\ldots\end{array}$ & $\begin{array}{r}-7.8 \\
\ldots \\
\ldots \\
\ldots\end{array}$ & $\begin{array}{r}-5.4 \\
-5.6 \\
0.2 \\
\ldots \\
\ldots\end{array}$ \\
\hline $\begin{array}{l}\text { Finland } \\
\text { National } \\
\text { Public } \\
\text { Private } \\
\text { Household } \\
\text { Corporate }\end{array}$ & $\begin{array}{r}25.4 \\
7.3 \\
18.0 \\
6.4 \\
11.6\end{array}$ & $\begin{array}{r}26.9 \\
7.8 \\
19.1 \\
7.1 \\
12.0\end{array}$ & $\begin{array}{r}24.4 \\
4.2 \\
20.2 \\
7.0 \\
13.2\end{array}$ & $\begin{array}{r}-1.0 \\
-3.0 \\
2.2 \\
0.6 \\
1.6\end{array}$ & $\begin{array}{r}-2.5 \\
-3.5 \\
1.1 \\
-0.1 \\
1.2\end{array}$ \\
\hline $\begin{array}{l}\text { Greece } \\
\text { National } \\
\text { Public } \\
\text { Private } \\
\text { Household } \\
\text { Corporate }\end{array}$ & $\begin{array}{r}19.2 \\
3.9 \\
15.3 \\
9.3 \\
6.0\end{array}$ & $\begin{array}{r}25.8 \\
2.3 \\
23.5 \\
16.0 \\
7.5\end{array}$ & $\begin{array}{r}17.4 \\
-7.3 \\
24.7 \\
16.0 \\
8.7\end{array}$ & $\begin{array}{r}-1.8 \\
-11.2 \\
9.4 \\
6.7 \\
2.7\end{array}$ & $\begin{array}{r}-8.4 \\
-9.6 \\
1.2 \\
0.0 \\
1.2\end{array}$ \\
\hline $\begin{array}{l}\text { Iceland } \\
\text { National } \\
\text { Public } \\
\text { Private } \\
\text { Household } \\
\text { Corporate }\end{array}$ & $\begin{array}{r}25.4 \\
\ldots \\
\ldots \\
\ldots\end{array}$ & $\begin{array}{r}24.8 \\
8.0 \\
16.9 \\
\ldots \\
\ldots\end{array}$ & $\begin{array}{r}18.7 \\
6.7 \\
12.0 \\
\ldots \\
\ldots\end{array}$ & $\begin{array}{r}-6.7 \\
\ldots \\
\ldots \\
\ldots\end{array}$ & $\begin{array}{r}-6.1 \\
-1.3 \\
-4.9 \\
\ldots \\
\ldots\end{array}$ \\
\hline $\begin{array}{l}\text { Ireland } \\
\text { National } \\
\text { Public } \\
\text { Private } \\
\text { Household } \\
\text { Corporate }\end{array}$ & $\begin{array}{r}18.4 \\
\ldots \\
\ldots \\
\ldots\end{array}$ & $\begin{array}{r}21.3 \\
\ldots \\
\ldots \\
\ldots\end{array}$ & $\begin{array}{r}18.6 \\
-6.9 \\
25.5 \\
\ldots \\
.\end{array}$ & $\begin{array}{c}0.2 \\
\ldots \\
\ldots \\
\ldots\end{array}$ & $\begin{array}{r}-2.7 \\
\cdots \\
\cdots \\
\cdots\end{array}$ \\
\hline
\end{tabular}


Table 1 (Continued)

\begin{tabular}{|c|c|c|c|c|c|}
\hline & 19603 & $1970 s$ & $1980 \mathrm{~s}$ & $\begin{array}{c}\text { Change } \\
1960 s\end{array}$ & $\begin{array}{l}\text { een } 1980 \mathrm{~s} \\
1970 \mathrm{~s}\end{array}$ \\
\hline $\begin{array}{l}\text { Netherlands } \\
\text { Natlonal } \\
\text { Public } \\
\text { Private } \\
\text { Household } \\
\text { Corporate }\end{array}$ & $\begin{array}{r}26.9 \\
4.6 \\
22.1 \\
\ldots \\
\ldots\end{array}$ & $\begin{array}{r}24.5 \\
3.3 \\
21.1 \\
9.5 \\
11.6\end{array}$ & $\begin{array}{r}22.2 \\
-0.6 \\
22.7 \\
9.4 \\
13.4\end{array}$ & $\begin{array}{r}-4.7 \\
-5.2 \\
0.6 \\
\ldots \\
\ldots\end{array}$ & $\begin{array}{r}-2.3 \\
-3.9 \\
1.6 \\
-0.1 \\
1.8\end{array}$ \\
\hline $\begin{array}{l}\text { New zealand } \\
\text { National } \\
\text { Public } \\
\text { Private } \\
\text { Household } \\
\text { Corporate }\end{array}$ & $\begin{array}{r}21.2 \\
\quad . \\
\quad . \\
\ldots\end{array}$ & $\begin{array}{r}22.0 \\
\quad . \\
\therefore \\
\therefore\end{array}$ & $\begin{array}{c}19.4 \\
\quad . \\
\quad \\
\quad\end{array}$ & $\begin{array}{r}-1.8 \\
\quad \therefore \\
\therefore \\
\therefore\end{array}$ & $\begin{array}{r}-2.6 \\
\therefore \\
\therefore \\
\therefore\end{array}$ \\
\hline $\begin{array}{l}\text { Norway } \\
\text { National } \\
\text { Publie } \\
\text { Private } \\
\text { Household } \\
\text { Corporate }\end{array}$ & $\begin{array}{r}27.4 \\
8.1 \\
19.2 \\
\ldots \\
\ldots\end{array}$ & $\begin{array}{r}26.8 \\
7.9 \\
18.8 \\
5.9 \\
12.7\end{array}$ & $\begin{array}{r}27.7 \\
8.7 \\
19.0 \\
4.0 \\
14.9\end{array}$ & $\begin{array}{r}0.3 \\
0.6 \\
-0.2 \\
\quad .\end{array}$ & $\begin{array}{r}0.9 \\
0.8 \\
0.2 \\
-1.9 \\
2.2\end{array}$ \\
\hline $\begin{array}{l}\text { Portugal } \\
\text { National } \\
\text { Public } \\
\text { Private } \\
\text { Household } \\
\text { Corporate }\end{array}$ & $\begin{array}{r}23.1 \\
\ldots \\
\ldots \\
\ldots\end{array}$ & $\begin{array}{c}26.0 \\
-1.3 \\
25.8 \\
\ldots \\
\ldots\end{array}$ & $\begin{array}{c}24.2 \\
-2.0 \\
25.2 \\
\ldots \\
\ldots\end{array}$ & $\begin{array}{c}1.1 \\
\therefore \\
\therefore \\
\therefore\end{array}$ & $\begin{array}{c}-1.8 \\
-0.7 \\
-0.6 \\
\ldots \\
\ldots\end{array}$ \\
\hline $\begin{array}{l}\text { Spain } \\
\text { National } \\
\text { Public } \\
\text { Private } \\
\text { Eousehold } \\
\text { Corporate }\end{array}$ & $\begin{array}{r}25.3 \\
\ldots \\
\ldots \\
\ldots\end{array}$ & $\begin{array}{r}25.6 \\
\ldots \\
\because \\
\because\end{array}$ & $\begin{array}{r}20.9 \\
-0.4 \\
20.5 \\
8.6 \\
11.9\end{array}$ & $\begin{array}{r}-4.4 \\
\ldots \\
\ldots \\
\ldots\end{array}$ & $\begin{array}{r}-4.7 \\
\quad . \\
\therefore \\
\therefore\end{array}$ \\
\hline $\begin{array}{l}\text { Swoden } \\
\text { National } \\
\text { Public } \\
\text { Private } \\
\text { Household } \\
\text { Corporate }\end{array}$ & $\begin{array}{r}24.0 \\
\quad . \\
\quad \therefore \\
\quad \therefore\end{array}$ & $\begin{array}{c}20.9 \\
\ldots \\
\ldots \\
\ldots\end{array}$ & $\begin{array}{r}17.2 \\
1.4 \\
15.6 \\
3.1 \\
12.2\end{array}$ & $\begin{array}{r}-6.8 \\
\quad . \\
\therefore \\
\therefore\end{array}$ & $\begin{array}{r}-3.7 \\
\quad . \\
\therefore \\
\therefore\end{array}$ \\
\hline $\begin{array}{l}\text { Switzerland } \\
\text { National } \\
\text { Public } \\
\text { Private } \\
\text { Household } \\
\text { Corporate }\end{array}$ & $\begin{array}{r}29.4 \\
4.5 \\
24.9 \\
7.9 \\
17.1\end{array}$ & $\begin{array}{r}28.6 \\
3.9 \\
24.8 \\
8.9 \\
15.9\end{array}$ & $\begin{array}{r}28.5 \\
3.6 \\
24.9 \\
9.1 \\
15.8\end{array}$ & $\begin{array}{r}-0.9 \\
-0.9 \\
0.0 \\
1.2 \\
-1.3\end{array}$ & $\begin{array}{r}-0.1 \\
-0.3 \\
0.1 \\
0.2 \\
-0.1\end{array}$ \\
\hline $\begin{array}{l}\text { Turkey } \\
\text { National } \\
\text { Public } \\
\text { Private } \\
\text { Household } \\
\text { Corporate }\end{array}$ & $\begin{array}{c}14.8 \\
\therefore \\
\therefore \\
\therefore\end{array}$ & $\begin{array}{r}17.1 \\
7.6 \\
10.1 \\
\ldots\end{array}$ & $\begin{array}{r}19.1 \\
\quad \ldots \\
\ldots \\
\ldots\end{array}$ & $\begin{array}{c}4.3 \\
\therefore \\
\therefore \\
\therefore\end{array}$ & $\begin{array}{c}2.0 \\
\therefore \\
\therefore \\
\therefore\end{array}$ \\
\hline
\end{tabular}


Table 2 Inflation adjusted private saving ratios (1)

\begin{tabular}{|c|c|c|c|c|c|}
\hline & \multirow[t]{2}{*}{$1960 \mathrm{~s}$} & \multirow[t]{2}{*}{$1970 \mathrm{~s}$} & \multirow[t]{2}{*}{$1980 \mathrm{~s}$} & \multicolumn{2}{|c|}{$\begin{array}{c}\text { Changes between } 1980 \mathrm{~s} \\
\text { and }\end{array}$} \\
\hline & & & & $1960 \mathrm{~s}$ & $1970 \mathrm{~s}$ \\
\hline United States & $\begin{array}{l}17.7 \\
17.1\end{array}$ & $\begin{array}{l}19.1 \\
17.8\end{array}$ & $\begin{array}{l}18.5 \\
17.7\end{array}$ & $\begin{array}{l}0.8 \\
0.6\end{array}$ & $\begin{array}{l}-0.6 \\
-0.1\end{array}$ \\
\hline Japan & $\begin{array}{l}28.3 \\
29.1\end{array}$ & $\begin{array}{l}30.4 \\
31.3\end{array}$ & $\begin{array}{l}26.7 \\
26.4\end{array}$ & $\begin{array}{l}-1.6 \\
-2.5\end{array}$ & $\begin{array}{l}-3.7 \\
-4.9\end{array}$ \\
\hline Germany & $\begin{array}{ll}21 & 1 \\
21.9\end{array}$ & $\begin{array}{l}20.4 \\
20.8\end{array}$ & $\begin{array}{l}20.5 \\
19.7\end{array}$ & $\begin{array}{l}-0.6 \\
-2.2\end{array}$ & $\begin{array}{r}0.1 \\
-1.1\end{array}$ \\
\hline France & $\cdots$ & $\begin{array}{l}22.2 \\
21.7\end{array}$ & $\begin{array}{l}19.0 \\
18.0\end{array}$ & $\begin{array}{l}\cdots \\
-\end{array}$ & $\begin{array}{l}-3.2 \\
-3.7\end{array}$ \\
\hline United Kingdom & $\begin{array}{l}14.8 \\
--\end{array}$ & $\begin{array}{r}153 \\
9.2\end{array}$ & $\begin{array}{l}16.6 \\
14.0\end{array}$ & $\begin{array}{ll}1.8 \\
--\end{array}$ & $\begin{array}{l}1.3 \\
4.8\end{array}$ \\
\hline Italy & $\begin{array}{l}26.0 \\
--\end{array}$ & $\begin{array}{l}31.1 \\
25.7\end{array}$ & $\begin{array}{l}28.4 \\
22.2\end{array}$ & 2.4 & $\begin{array}{l}-27 \\
-3.5\end{array}$ \\
\hline Canada & $\begin{array}{l}18.2 \\
18.2\end{array}$ & $\begin{array}{l}20.1 \\
195\end{array}$ & $\begin{array}{l}22.3 \\
22.2\end{array}$ & $\begin{array}{l}4.1 \\
4.0\end{array}$ & $\begin{array}{l}2.2 \\
2.7\end{array}$ \\
\hline Australia & $\begin{array}{l}\cdots \\
\cdots\end{array}$ & $\begin{array}{l}21.1 \\
18.8\end{array}$ & $\begin{array}{l}18.3 \\
16.5\end{array}$ & $\begin{array}{l}-\cdot \\
--\end{array}$ & $\begin{array}{l}-28 \\
-2.3\end{array}$ \\
\hline Belgium & $\begin{array}{l}21.0 \\
--\end{array}$ & $\begin{array}{l}22.7 \\
19.6\end{array}$ & $\begin{array}{l}21.8 \\
18.1\end{array}$ & $\begin{array}{l}0.8 \\
--\end{array}$ & $\begin{array}{l}-0.9 \\
-1.5\end{array}$ \\
\hline Denmark & $\cdots$ & $\begin{array}{l}14.9 \\
16.3\end{array}$ & $\begin{array}{l}15.1 \\
14.8\end{array}$ & $\cdots$ & $\begin{array}{r}0.2 \\
-1.5\end{array}$ \\
\hline Finland & $\begin{array}{l}18.0 \\
\ldots\end{array}$ & $\begin{array}{l}19.1 \\
20.0\end{array}$ & $\begin{array}{l}20.2 \\
21.0\end{array}$ & $\begin{array}{l}2.2 \\
--\end{array}$ & $\begin{array}{l}1.1 \\
1.0\end{array}$ \\
\hline Greece & $\begin{array}{l}15.3 \\
15.0\end{array}$ & $\begin{array}{l}23.5 \\
21.1\end{array}$ & $\begin{array}{l}24.7 \\
20.7\end{array}$ & $\begin{array}{l}9.4 \\
5.7\end{array}$ & $\begin{array}{r}1.2 \\
-0.4\end{array}$ \\
\hline Netherlands & $\begin{array}{l}22.1 \\
--\end{array}$ & $\begin{array}{l}21.1 \\
19.8\end{array}$ & $\begin{array}{l}22.7 \\
21.2\end{array}$ & $\begin{array}{l}0.6 \\
--\end{array}$ & $\begin{array}{l}1.6 \\
1.4\end{array}$ \\
\hline Norway & $\begin{array}{l}19.2 \\
-.\end{array}$ & $\begin{array}{l}18.8 \\
19.4\end{array}$ & $\begin{array}{l}19.0 \\
20.2\end{array}$ & $\begin{array}{l}-0.2 \\
--\end{array}$ & $\begin{array}{l}0.2 \\
0.8\end{array}$ \\
\hline
\end{tabular}

1 Adjusted series are in bold.

Source. OECD National Accounts and Secretariat estimates. 
Table 3. National saving ratios and adjustments for public expenditure in higher and total education

\begin{tabular}{|c|c|c|c|c|}
\hline & & $1970 \mathrm{~s}$ & $1980 \mathrm{~s}$ & $\begin{array}{c}\text { Change between } 1980 \mathrm{~s} \\
\text { and } \\
1970 \mathrm{~s}\end{array}$ \\
\hline United States & $\begin{array}{l}(i) \\
(2) \\
(3)\end{array}$ & $\begin{array}{l}19.4 \\
20.7 \\
24.5\end{array}$ & $\begin{array}{l}16.4 \\
17.6 \\
21.0\end{array}$ & $\begin{array}{l}-3.0 \\
-3.1 \\
-3.5\end{array}$ \\
\hline Japan & $\begin{array}{l}(1) \\
(2) \\
(3)\end{array}$ & $\begin{array}{l}35.3 \\
35.8 \\
39.9\end{array}$ & $\begin{array}{l}31.4 \\
32.0 \\
36.3\end{array}$ & $\begin{array}{l}-3.9 \\
-3.9 \\
-3.7\end{array}$ \\
\hline Germany & $\begin{array}{l}(1) \\
(2) \\
(3)\end{array}$ & $\begin{array}{l}24.3 \\
25.0 \\
28.9\end{array}$ & $\begin{array}{l}22.1 \\
22.8 \\
26.4\end{array}$ & $\begin{array}{l}-2.2 \\
-2.3 \\
-2.4\end{array}$ \\
\hline France & $\begin{array}{l}(1) \\
(2) \\
(3)\end{array}$ & $\begin{array}{l}25.8 \\
26.5 \\
31.0\end{array}$ & $\begin{array}{l}20.3 \\
20.9 \\
25.8\end{array}$ & $\begin{array}{l}-5.6 \\
-5.6 \\
-5.1\end{array}$ \\
\hline United Kingdom & $\begin{array}{l}(1) \\
(2) \\
(3)\end{array}$ & $\begin{array}{l}17.9 \\
19.2 \\
23.7\end{array}$ & $\begin{array}{l}16.7 \\
17.9 \\
21.9\end{array}$ & $\begin{array}{l}-1.1 \\
-1.3 \\
-1.7\end{array}$ \\
\hline Italy & $\begin{array}{l}(1) \\
(2) \\
(3)\end{array}$ & $\begin{array}{l}25.9 \\
26.4 \\
30.2\end{array}$ & $\begin{array}{l}22.1 \\
22.7 \\
26.9\end{array}$ & $\begin{array}{l}-3.9 \\
-3.8 \\
-3.3\end{array}$ \\
\hline Canada & $\begin{array}{l}(1) \\
(2) \\
(3)\end{array}$ & $\begin{array}{l}22.9 \\
25.1 \\
30.7\end{array}$ & $\begin{array}{l}20.7 \\
22.8 \\
28.1\end{array}$ & $\begin{array}{l}-2.1 \\
-2.3 \\
-2.6\end{array}$ \\
\hline
\end{tabular}

1. National saving as a per cent of GNP.

2. National saving plus higher education expenditures as a per cent of GNE.

3. National saving plus total education expenditures as a per cent of GNP . 
Table 3 (Continued)

\begin{tabular}{|c|c|c|c|c|}
\hline & & $1970 \mathrm{~s}$ & $1980 \mathrm{~s}$ & $\begin{array}{c}\text { Change between } 1980 \mathrm{~s} \\
\text { and } \\
1970 \mathrm{~s}\end{array}$ \\
\hline Australia & $\begin{array}{l}(1) \\
(2) \\
(3)\end{array}$ & $\begin{array}{l}24.0 \\
25.7 \\
29.3\end{array}$ & $\begin{array}{l}20.0 \\
21.7 \\
25.5\end{array}$ & $\begin{array}{l}-4.0 \\
-4.0 \\
-3.7\end{array}$ \\
\hline Austria & $\begin{array}{l}(1) \\
(2) \\
(3)\end{array}$ & $\begin{array}{l}28.0 \\
28.8 \\
33.3\end{array}$ & $\begin{array}{l}24.1 \\
25.1 \\
30.0\end{array}$ & $\begin{array}{l}-3.9 \\
-3.7 \\
-3.3\end{array}$ \\
\hline Belgium & $\begin{array}{l}(1) \\
(2) \\
(3)\end{array}$ & $\begin{array}{l}22.7 \\
22.4 \\
28.1\end{array}$ & $\begin{array}{l}15.9 \\
16.9 \\
21.5\end{array}$ & $\begin{array}{l}-6.8 \\
-6.8 \\
-6.8\end{array}$ \\
\hline Denmark & $\begin{array}{l}(1) \\
(2) \\
(3)\end{array}$ & $\begin{array}{l}20.9 \\
22.4 \\
28.1\end{array}$ & $\begin{array}{l}15.2 \\
16.2 \\
21.0\end{array}$ & $\begin{array}{l}-5.8 \\
-6.2 \\
-7.0\end{array}$ \\
\hline Finland & $\begin{array}{l}(1) \\
(2) \\
(3)\end{array}$ & $\begin{array}{l}26.9 \\
28.0 \\
32.6\end{array}$ & $\begin{array}{l}24.2 \\
25.3 \\
29.9\end{array}$ & $\begin{array}{l}-2.7 \\
-2.7 \\
-2.8\end{array}$ \\
\hline Greece & $\begin{array}{l}(1) \\
(2) \\
(3)\end{array}$ & $\begin{array}{l}25.8 \\
26.3 \\
28.6\end{array}$ & $\begin{array}{l}17.7 \\
18.4 \\
21.1\end{array}$ & $\begin{array}{l}-8.1 \\
-7.9 \\
-7.5\end{array}$ \\
\hline Ireland & $\begin{array}{l}(1) \\
(2) \\
(3)\end{array}$ & $\begin{array}{l}21.3 \\
22.3 \\
27.1\end{array}$ & $\begin{array}{l}18.2 \\
19.4 \\
24.9\end{array}$ & $\begin{array}{l}-3.2 \\
-2.9 \\
-2.2\end{array}$ \\
\hline Netherlands & $\begin{array}{l}(1) \\
(2) \\
(3)\end{array}$ & $\begin{array}{l}23.9 \\
26.6 \\
31.9\end{array}$ & $\begin{array}{l}21.9 \\
23.9 \\
29.0\end{array}$ & $\begin{array}{l}-2.6 \\
-2.7 \\
-2.8\end{array}$ \\
\hline New Zeal and & $\begin{array}{l}(1) \\
(2) \\
(3)\end{array}$ & $\begin{array}{l}22.0 \\
23.3 \\
27.4\end{array}$ & $\begin{array}{l}19.4 \\
20.5 \\
24.7\end{array}$ & $\begin{array}{l}-2.6 \\
-2.9 \\
-2.6\end{array}$ \\
\hline Norway & $\begin{array}{l}(1) \\
(2) \\
(3)\end{array}$ & $\begin{array}{l}26.8 \\
27.7 \\
33.9\end{array}$ & $\begin{array}{l}27.9 \\
28.8 \\
34.1\end{array}$ & $\begin{array}{l}1.2 \\
1.1 \\
0.2\end{array}$ \\
\hline Portugal & $\begin{array}{l}(1) \\
(2) \\
(3)\end{array}$ & $\begin{array}{l}26.0 \\
26.4 \\
29.6\end{array}$ & $\begin{array}{l}23.9 \\
24.9 \\
28.3\end{array}$ & $\begin{array}{l}-2.0 \\
-1.9 \\
-1.4\end{array}$ \\
\hline Sweden & $\begin{array}{l}(1) \\
(2) \\
(3)\end{array}$ & $\begin{array}{r}20.9 \\
28.4\end{array}$ & $\begin{array}{r}17.0 \\
\quad \ldots \\
24.6\end{array}$ & $\begin{array}{r}-3.9 \\
-3.8\end{array}$ \\
\hline Switzerland & $\begin{array}{l}(1) \\
(2) \\
(3)\end{array}$ & $\begin{array}{l}28.6 \\
29.5 \\
33.3\end{array}$ & $\begin{array}{l}28.1 \\
29.0 \\
32.9\end{array}$ & $\begin{array}{l}-0.5 \\
-0.4 \\
-0.4\end{array}$ \\
\hline
\end{tabular}


Table 4. National saving ratios and adjustments for private consumption expenditure in durable goods (1)

\begin{tabular}{|c|c|c|c|c|c|}
\hline & \multirow[b]{2}{*}{$1960 s$} & \multirow[b]{2}{*}{$1970 \mathrm{~s}$} & \multirow[b]{2}{*}{$1980 s$} & \multicolumn{2}{|c|}{$\begin{array}{c}\text { Change between } 1980 \mathrm{~s} \\
\text { and }\end{array}$} \\
\hline & & & & $1960 \mathrm{~s}$ & $1970 \mathrm{~s}$ \\
\hline United States & $\begin{array}{l}19.7 \\
24.9\end{array}$ & $\begin{array}{l}19.4 \\
24.7\end{array}$ & $\begin{array}{l}16.3 \\
21.8\end{array}$ & $\begin{array}{l}-3.4 \\
-3.0\end{array}$ & $\begin{array}{l}-3.1 \\
-2.9\end{array}$ \\
\hline Japan & $\begin{array}{r}34.5 \\
\ldots\end{array}$ & $\begin{array}{l}35.3 \\
37.4\end{array}$ & $\begin{array}{l}31.6 \\
33.9\end{array}$ & $\begin{array}{r}-2.9 \\
\ldots\end{array}$ & $\begin{array}{l}-3.7 \\
-3.5\end{array}$ \\
\hline France & $\begin{array}{r}26.2 \\
\ldots\end{array}$ & $\begin{array}{l}25.8 \\
29.3\end{array}$ & $\begin{array}{l}20.4 \\
24.2\end{array}$ & $\begin{array}{r}-5.8 \\
\ldots\end{array}$ & $\begin{array}{l}-5.5 \\
-5.0\end{array}$ \\
\hline United Kingdom & $\begin{array}{l}18.4 \\
22.6\end{array}$ & $\begin{array}{l}17.9 \\
22.4\end{array}$ & $\begin{array}{l}16.6 \\
21.3\end{array}$ & $\begin{array}{l}-1.8 \\
-1.2\end{array}$ & $\begin{array}{l}-1.3 \\
-1.0\end{array}$ \\
\hline Canada & $\begin{array}{l}21.9 \\
28.1\end{array}$ & $\begin{array}{l}22.9 \\
29.1\end{array}$ & $\begin{array}{l}20.7 \\
27.0\end{array}$ & $\begin{array}{l}-1.2 \\
-1.2\end{array}$ & $\begin{array}{l}-2.1 \\
-2.2\end{array}$ \\
\hline Austria & $\begin{array}{l}27.7 \\
32.4\end{array}$ & $\begin{array}{l}28.0 \\
33.0\end{array}$ & $\begin{array}{l}15.5 \\
29.1\end{array}$ & $\begin{array}{l}-7.8 \\
-3.3\end{array}$ & $\begin{array}{l}-5.5 \\
-3.9\end{array}$ \\
\hline Denmark & $\begin{array}{l}23.3 \\
28.3\end{array}$ & $\begin{array}{l}20.9 \\
26.1\end{array}$ & $\begin{array}{l}15.5 \\
20.2\end{array}$ & $\begin{array}{l}-7.8 \\
-8.1\end{array}$ & $\begin{array}{l}-5.5 \\
-5.9\end{array}$ \\
\hline Finland & $\begin{array}{l}25.4 \\
28.8\end{array}$ & $\begin{array}{l}25.8 \\
28.5\end{array}$ & $\begin{array}{l}17.4 \\
21.4\end{array}$ & $\begin{array}{r}-1.8 \\
\ldots\end{array}$ & $\begin{array}{l}-8.4 \\
-7.1\end{array}$ \\
\hline Greece & $\begin{array}{r}19.2 \\
\ldots\end{array}$ & $\begin{array}{l}25.8 \\
28.5\end{array}$ & $\begin{array}{l}17.4 \\
21.4\end{array}$ & $\begin{array}{r}-1.8 \\
\ldots\end{array}$ & $\begin{array}{l}-8.4 \\
-7.1\end{array}$ \\
\hline Netherlands & $\begin{array}{r}26.9 \\
\ldots\end{array}$ & $\begin{array}{l}24.5 \\
30.5\end{array}$ & $\begin{array}{l}22.2 \\
26.7\end{array}$ & $\begin{array}{r}-4.8 \\
\ldots\end{array}$ & $\begin{array}{l}-2.3 \\
-3.8\end{array}$ \\
\hline Norway & $\begin{array}{l}27.4 \\
31.3\end{array}$ & $\begin{array}{l}26.8 \\
31.3\end{array}$ & $\begin{array}{l}27.7 \\
31.9\end{array}$ & $\begin{array}{l}0.3 \\
0.6\end{array}$ & $\begin{array}{l}0.9 \\
0.7\end{array}$ \\
\hline Portugal & $\begin{array}{r}23.1 \\
\ldots\end{array}$ & $\begin{array}{r}26.0 \\
29.6\end{array}$ & $\begin{array}{l}24.2 \\
28.5\end{array}$ & $\begin{array}{r}1.1 \\
. .\end{array}$ & $\begin{array}{l}-1.7 \\
-1.1\end{array}$ \\
\hline Sweden & $\begin{array}{r}24.0 \\
\ldots\end{array}$ & $\begin{array}{r}20.9 \\
\ldots\end{array}$ & $\begin{array}{l}17.2 \\
21.2\end{array}$ & $\begin{array}{r}-6.7 \\
.\end{array}$ & $\begin{array}{r}-3.7 \\
.\end{array}$ \\
\hline
\end{tabular}

1. Adjusted series in bold. Adjusted series as a share of GNP plus expenditure on durable goods. 
Table 5. National saving ratios and adjustments for business and total R\&D

\begin{tabular}{|c|c|c|c|c|c|c|}
\hline & & \multirow[b]{2}{*}{$1960 \mathrm{~s}$} & \multirow[b]{2}{*}{$1970 \mathrm{~s}$} & \multirow[b]{2}{*}{$1980 s$} & \multicolumn{2}{|c|}{$\begin{array}{c}\text { Change between } 1980 \mathrm{~s} \\
\text { and }\end{array}$} \\
\hline & & & & & $1960 \mathrm{~s}$ & $1970 \mathrm{~s}$ \\
\hline United States & $\begin{array}{l}(1) \\
(2) \\
(3)\end{array}$ & $\begin{array}{l}19.7 \\
21.3 \\
22.2\end{array}$ & $\begin{array}{l}19.4 \\
20.7 \\
21.4\end{array}$ & $\begin{array}{l}16.3 \\
17.9 \\
18.7\end{array}$ & $\begin{array}{l}-3.4 \\
-3.4 \\
-3.5\end{array}$ & $\begin{array}{l}-3.1 \\
-2.8 \\
-2.8\end{array}$ \\
\hline Japan & $\begin{array}{l}(1) \\
(2) \\
(3)\end{array}$ & $\begin{array}{l}34.5 \\
35.1 \\
35.8\end{array}$ & $\begin{array}{l}35.3 \\
36.0 \\
36.8\end{array}$ & $\begin{array}{l}31.6 \\
32.8 \\
33.7\end{array}$ & $\begin{array}{l}-2.9 \\
-2.3 \\
-2.1\end{array}$ & $\begin{array}{l}-3.7 \\
-3.2 \\
-3.2\end{array}$ \\
\hline Germany & $\begin{array}{l}(1) \\
(2) \\
(3)\end{array}$ & $\begin{array}{l}27.3 \\
28.0 \\
28.7\end{array}$ & $\begin{array}{l}24.3 \\
25.3 \\
26.1\end{array}$ & $\begin{array}{l}22.5 \\
24.0 \\
24.7\end{array}$ & $\begin{array}{l}-4.7 \\
-4.1 \\
-3.9\end{array}$ & $\begin{array}{l}-1.8 \\
-1.3 \\
-1.4\end{array}$ \\
\hline France & $\begin{array}{l}(1) \\
(2) \\
(3)\end{array}$ & $\begin{array}{l}26.2 \\
26.9 \\
27.8\end{array}$ & $\begin{array}{l}25.8 \\
26.6 \\
27.3\end{array}$ & $\begin{array}{l}20.4 \\
21.4 \\
22.2\end{array}$ & $\begin{array}{l}-5.8 \\
-5.5 \\
-5.6\end{array}$ & $\begin{array}{l}-5.5 \\
-5.2 \\
-5.1\end{array}$ \\
\hline United Kingdom & $\begin{array}{l}(1) \\
(2) \\
(3)\end{array}$ & $\begin{array}{l}18.4 \\
19.5 \\
20.3\end{array}$ & $\begin{array}{l}17.9 \\
18.9 \\
19.7\end{array}$ & $\begin{array}{l}16.6 \\
17.8 \\
18.6\end{array}$ & $\begin{array}{l}-1.8 \\
-1.7 \\
-1.7\end{array}$ & $\begin{array}{l}-1.3 \\
-1.1 \\
-1.0\end{array}$ \\
\hline Italy & $\begin{array}{l}(1) \\
(2) \\
(3)\end{array}$ & $\begin{array}{l}28.1 \\
28.4 \\
28.7\end{array}$ & $\begin{array}{l}25.9 \\
26.3 \\
26.3\end{array}$ & $\begin{array}{l}21.9 \\
22.4 \\
22.8\end{array}$ & $\begin{array}{l}-6.2 \\
-6.0 \\
-5.9\end{array}$ & $\begin{array}{l}-4.0 \\
-3.9 \\
-3.8\end{array}$ \\
\hline Canada & $\begin{array}{l}(1) \\
(2) \\
(3)\end{array}$ & $\begin{array}{l}21.9 \\
22.2 \\
23.0\end{array}$ & $\begin{array}{l}22.9 \\
23.2 \\
23.9\end{array}$ & $\begin{array}{l}20.7 \\
21.3 \\
21.9\end{array}$ & $\begin{array}{l}-1.2 \\
-1.0 \\
-1.1\end{array}$ & $\begin{array}{l}-2.1 \\
-1.9 \\
-2.0\end{array}$ \\
\hline
\end{tabular}

1. National saving as a per cent of GNP.

2. National saving plus business R\&D as a per cent of GNP plus business R\&D.

3. National saving plus total R\&D as a per cent of GNP plus business R\&D. 
Table 5. (Continued)

\begin{tabular}{|c|c|c|c|c|c|c|}
\hline & & \multirow[b]{2}{*}{$1960 s$} & \multirow[b]{2}{*}{$1970 \mathrm{~s}$} & \multirow[b]{2}{*}{19808} & \multicolumn{2}{|c|}{$\begin{array}{c}\text { Change between } 1980 \mathrm{~s} \\
\text { and }\end{array}$} \\
\hline & & & & & 19600 & 19708 \\
\hline Australla & $\begin{array}{l}(1) \\
(2) \\
(3)\end{array}$ & $\begin{array}{l}24.7 \\
25.1 \\
25.9\end{array}$ & $\begin{array}{l}24.0 \\
24.2 \\
25.0\end{array}$ & $\begin{array}{l}20 \cdot 2 \\
20 \cdot 5 \\
21.3\end{array}$ & $\begin{array}{l}-4.5 \\
-4.5 \\
-4.6\end{array}$ & $\begin{array}{l}-3.8 \\
-3.7 \\
-3.6\end{array}$ \\
\hline Austria & $\begin{array}{l}(1) \\
(2) \\
(3)\end{array}$ & $\begin{array}{r}27.7 \\
28.0 \\
\ldots\end{array}$ & $\begin{array}{l}28.0 \\
28.4 \\
28.8\end{array}$ & $\begin{array}{l}24.3 \\
24.9 \\
25.4\end{array}$ & $\begin{array}{r}-3.4 \\
-3.1 \\
\ldots\end{array}$ & $\begin{array}{l}-3.7 \\
-3.5 \\
-3.4\end{array}$ \\
\hline Belg1um & $\begin{array}{l}(1) \\
(2) \\
(3)\end{array}$ & $\begin{array}{l}22.2 \\
22.7 \\
23.1\end{array}$ & $\begin{array}{l}22.7 \\
23.4 \\
23.9\end{array}$ & $\begin{array}{l}16.4 \\
17.3 \\
17.8\end{array}$ & $\begin{array}{l}-5.8 \\
-5.4 \\
-5.3\end{array}$ & $\begin{array}{l}-6.4 \\
-6.1 \\
-6.1\end{array}$ \\
\hline Denmark & $\begin{array}{l}(1) \\
(2) \\
(3)\end{array}$ & $\begin{array}{l}23.3 \\
23.6 \\
24.0\end{array}$ & $\begin{array}{l}20.9 \\
21.3 \\
21.8\end{array}$ & $\begin{array}{l}15.5 \\
16.1 \\
16.7\end{array}$ & $\begin{array}{l}-7.8 \\
-7.4 \\
-7.3\end{array}$ & $\begin{array}{l}-5.5 \\
-5.2 \\
-5.1\end{array}$ \\
\hline rinland & $\begin{array}{l}\text { (1) } \\
\text { (2) } \\
\text { (3) }\end{array}$ & $\begin{array}{l}25.4 \\
25.6 \\
26.0\end{array}$ & $\begin{array}{l}26.9 \\
27.2 \\
27.7\end{array}$ & $\begin{array}{l}24.4 \\
25.1 \\
25.8\end{array}$ & $\begin{array}{l}-1.0 \\
-0.5 \\
-0.3\end{array}$ & $\begin{array}{l}-2.5 \\
-2.1 \\
-1.9\end{array}$ \\
\hline Grooce & $\begin{array}{l}(1) \\
(2) \\
(3)\end{array}$ & $\begin{array}{r}19.2 \\
\ldots \\
\ldots\end{array}$ & $\begin{array}{r}25.8 \\
\ldots \\
\ldots\end{array}$ & $\begin{array}{l}17.4 \\
17.5 \\
17.7\end{array}$ & $\begin{array}{r}-1.8 \\
\cdots \\
\cdots\end{array}$ & $\begin{array}{r}-8.4 \\
. \\
.\end{array}$ \\
\hline Iceland & $\begin{array}{l}(1) \\
(2) \\
(3)\end{array}$ & $\begin{array}{r}25.4 \\
\ldots \\
\ldots\end{array}$ & $\begin{array}{l}24.8 \\
24.8 \\
25.4\end{array}$ & $\begin{array}{l}18.7 \\
18.8 \\
19.5\end{array}$ & $\begin{array}{r}-6.7 \\
\cdots \\
\cdots\end{array}$ & $\begin{array}{l}-6.0 \\
-6.0 \\
-5.9\end{array}$ \\
\hline Iroland & $\begin{array}{l}(1) \\
(2) \\
(3)\end{array}$ & $\begin{array}{l}18.4 \\
18.6 \\
19.0\end{array}$ & $\begin{array}{l}21 \cdot 3 \\
21 \cdot 5 \\
22.0\end{array}$ & $\begin{array}{l}18.6 \\
19.0 \\
19.4\end{array}$ & $\begin{array}{l}0.2 \\
0.4 \\
0.4\end{array}$ & $\begin{array}{l}-2.7 \\
-2.6 \\
-2.6\end{array}$ \\
\hline Netherlands & $\begin{array}{l}(1) \\
(2) \\
(3)\end{array}$ & $\begin{array}{l}26.9 \\
27.7 \\
28.6\end{array}$ & $\begin{array}{l}24.5 \\
25.3 \\
26.2\end{array}$ & $\begin{array}{l}22.2 \\
23.1 \\
24.0\end{array}$ & $\begin{array}{l}-4.8 \\
-4.6 \\
-4.6\end{array}$ & $\begin{array}{l}-2 \cdot 3 \\
-2 \cdot 2 \\
-2 \cdot 2\end{array}$ \\
\hline New Zealand & $\begin{array}{l}(1) \\
(2) \\
(3)\end{array}$ & $\begin{array}{r}21.2 \\
\ldots \\
\ldots\end{array}$ & $\begin{array}{l}22.0 \\
22.1 \\
22.8\end{array}$ & $\begin{array}{r}19.3 \\
\ldots \\
\ldots\end{array}$ & $\begin{array}{r}-1.8 \\
\cdots \\
\cdots\end{array}$ & $\begin{array}{r}-2.6 \\
. . \\
.\end{array}$ \\
\hline Norway & $\begin{array}{l}(1) \\
(2) \\
(3)\end{array}$ & $\begin{array}{l}27.4 \\
27.7 \\
28.2\end{array}$ & $\begin{array}{l}26.8 \\
27.2 \\
27.9\end{array}$ & $\begin{array}{l}27.7 \\
28.3 \\
29.0\end{array}$ & $\begin{array}{l}0.3 \\
0.6 \\
0.7\end{array}$ & $\begin{array}{l}0.9 \\
1.1 \\
1.1\end{array}$ \\
\hline Portugal & $\begin{array}{l}(1) \\
(2) \\
(3)\end{array}$ & $\begin{array}{l}23.1 \\
23.2 \\
23.4\end{array}$ & $\begin{array}{l}26.0 \\
26.0 \\
26.3\end{array}$ & $\begin{array}{l}24.2 \\
24.3 \\
24.6\end{array}$ & $\begin{array}{l}1.1 \\
1.2 \\
1.3\end{array}$ & $\begin{array}{l}-1.7 \\
-1.7 \\
-1.7\end{array}$ \\
\hline Spain & $\begin{array}{l}(1) \\
(2) \\
(3)\end{array}$ & $\begin{array}{l}25.3 \\
25.4 \\
25.5\end{array}$ & $\begin{array}{l}25.6 \\
25.7 \\
25.8\end{array}$ & $\begin{array}{l}20.9 \\
21.1 \\
21.4\end{array}$ & $\begin{array}{l}-4.4 \\
-4.3 \\
-4.1\end{array}$ & $\begin{array}{l}-4.7 \\
-4.6 \\
-4.5\end{array}$ \\
\hline sweden & $\begin{array}{l}(1) \\
(2) \\
(3)\end{array}$ & $\begin{array}{l}24.0 \\
24.6 \\
25.0\end{array}$ & $\begin{array}{l}20.9 \\
21.8 \\
22.4\end{array}$ & $\begin{array}{l}17.2 \\
18.7 \\
19.6\end{array}$ & $\begin{array}{l}-6.7 \\
-6.0 \\
-5.4\end{array}$ & $\begin{array}{l}-3.7 \\
-3.1 \\
-2.8\end{array}$ \\
\hline sultzerland & $\begin{array}{l}(1) \\
(2) \\
(3)\end{array}$ & $\begin{array}{l}29.4 \\
30.7 \\
31.2\end{array}$ & $\begin{array}{l}28.6 \\
29.8 \\
30.3\end{array}$ & $\begin{array}{l}28.5 \\
39.7 \\
30.3\end{array}$ & $\begin{array}{l}-0.9 \\
-1.0 \\
-0.8\end{array}$ & $\begin{array}{r}-0.1 \\
-0.1 \\
0.0\end{array}$ \\
\hline Turkey & $\begin{array}{l}(1) \\
(2) \\
(3)\end{array}$ & $\begin{array}{r}14.8 \\
\ldots \\
\ldots\end{array}$ & $\begin{array}{r}17.1 \\
\ldots \\
.\end{array}$ & $\begin{array}{l}19.1 \\
19.4 \\
19.6\end{array}$ & $\begin{array}{c}4.3 \\
\ldots \\
\ldots\end{array}$ & $\begin{array}{r}2.0 \\
\ldots \\
\ldots\end{array}$ \\
\hline
\end{tabular}




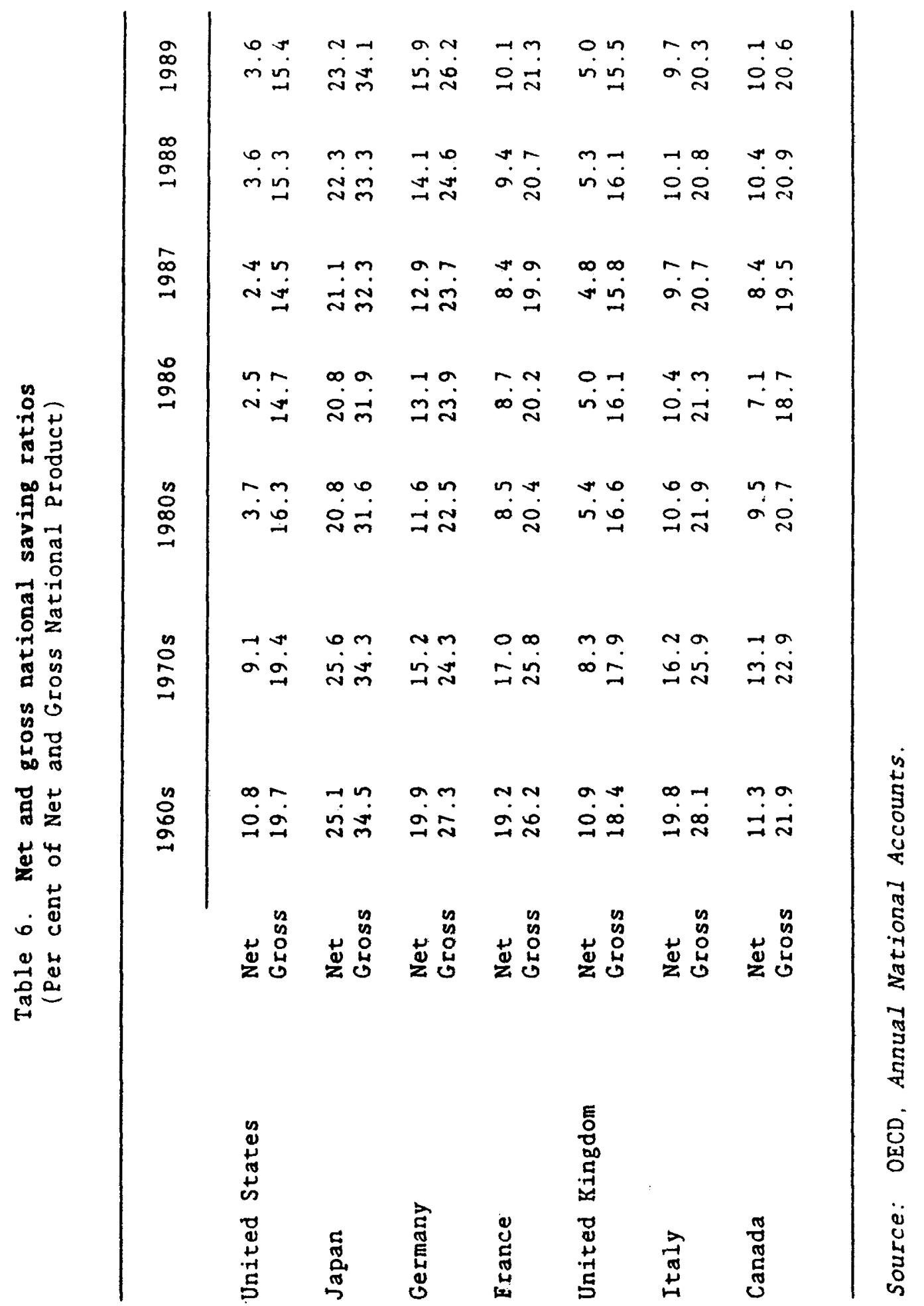




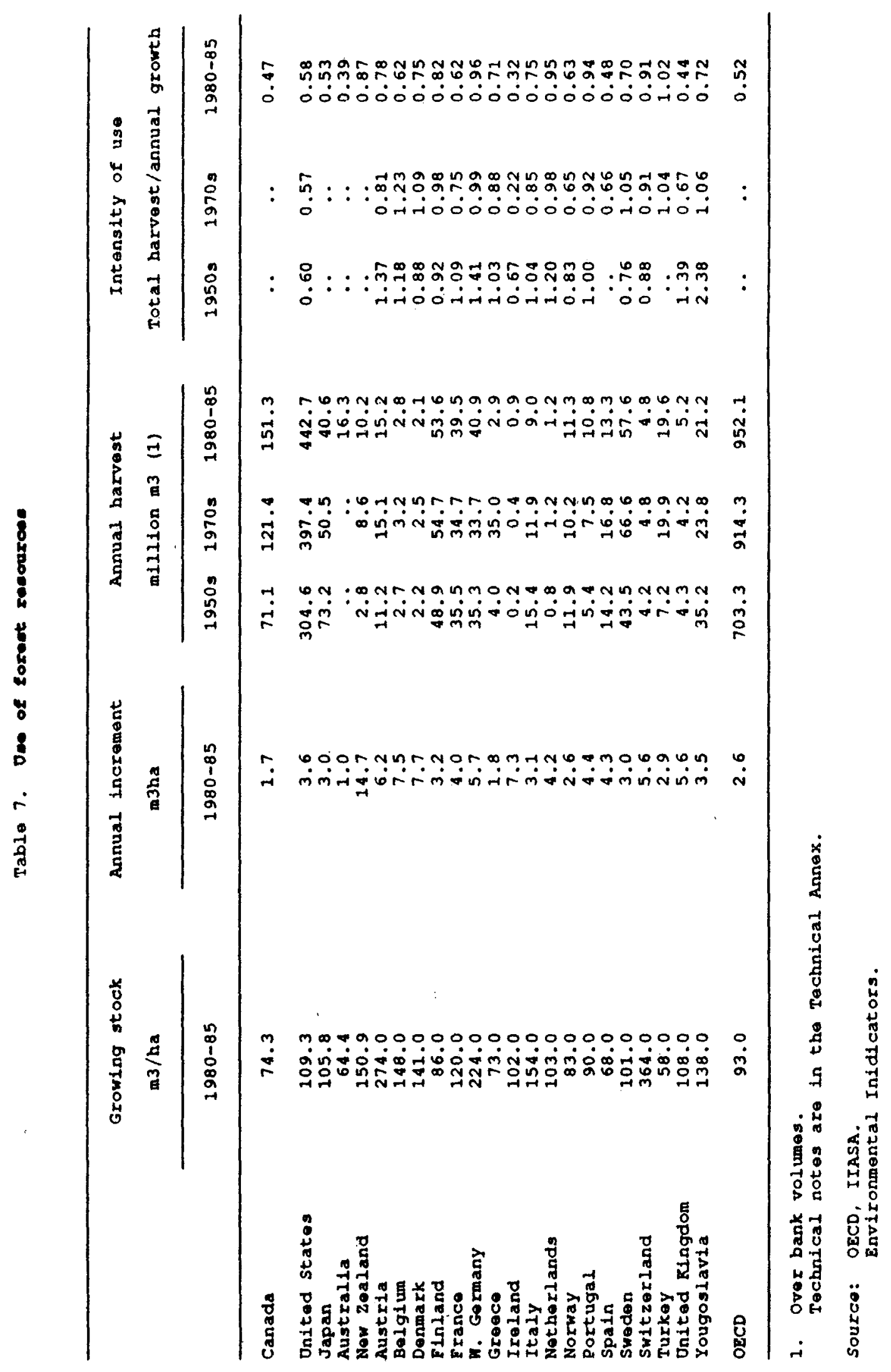


World

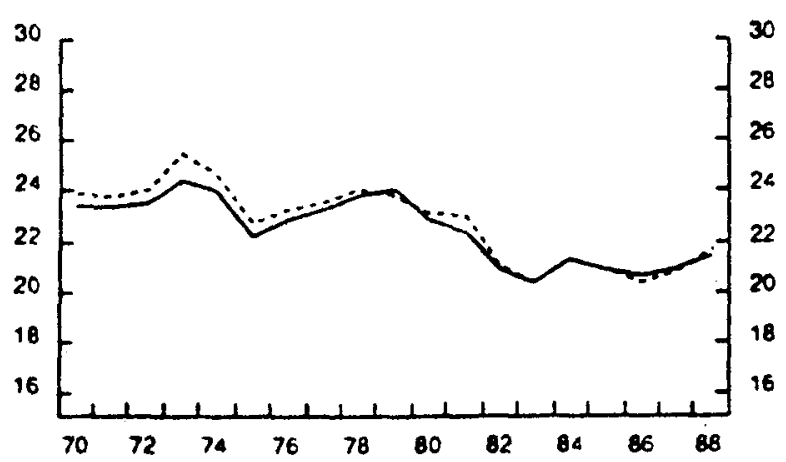

Gross Investment

Gross Saving

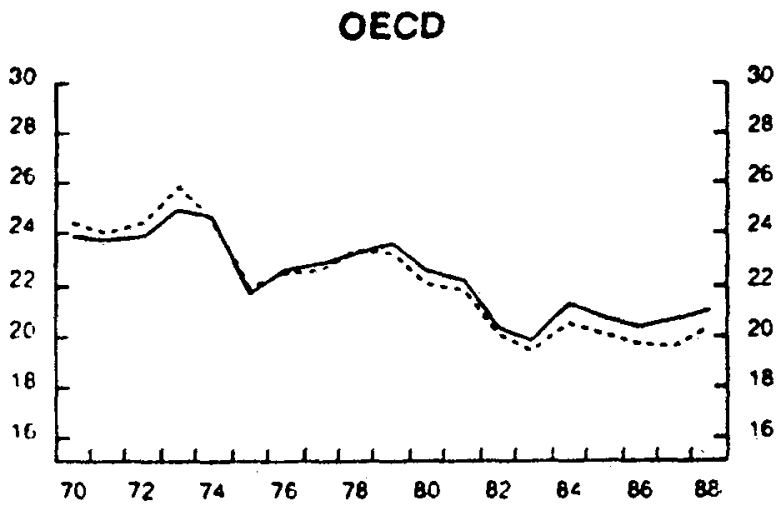

NON OECD

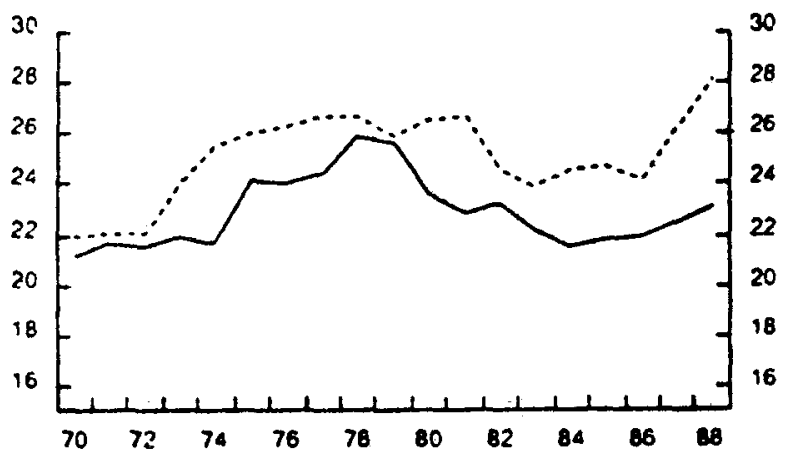

Asian NIE's
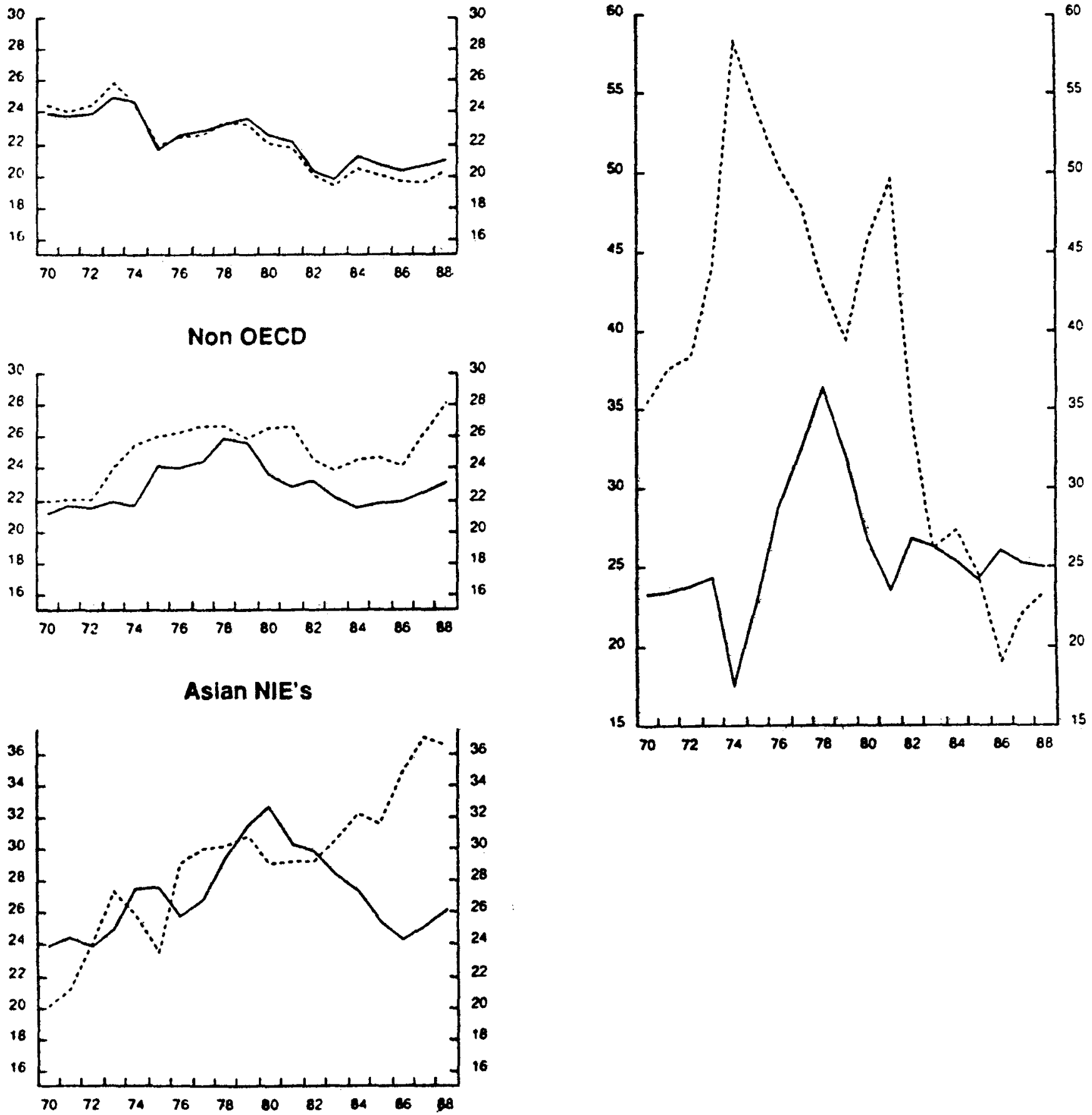

Source. World Bank and OECD National Accounts. 
Shart $B$

Investment and saving ratios in OECD countries

(percentage of GNP)

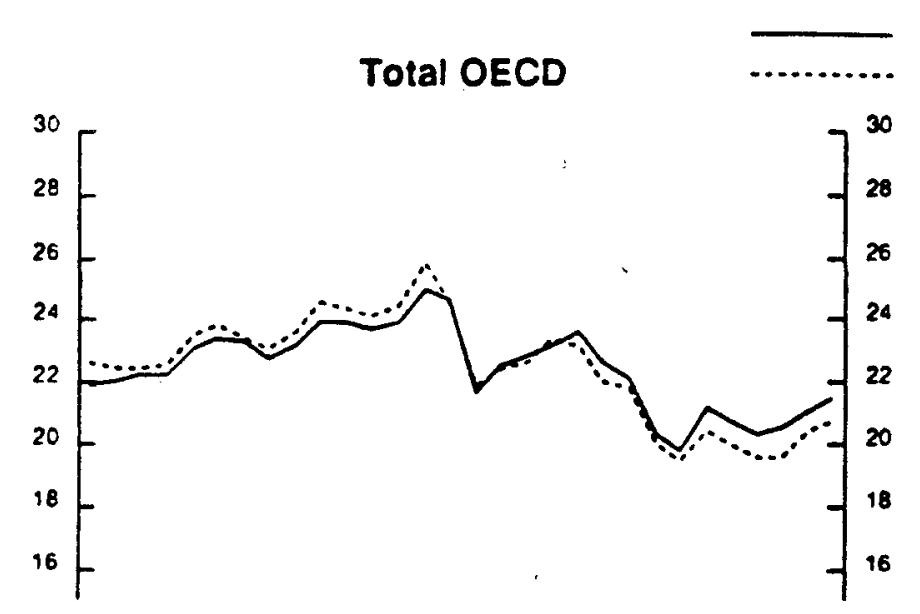

Gross investment

Gross saving

United States

Japan

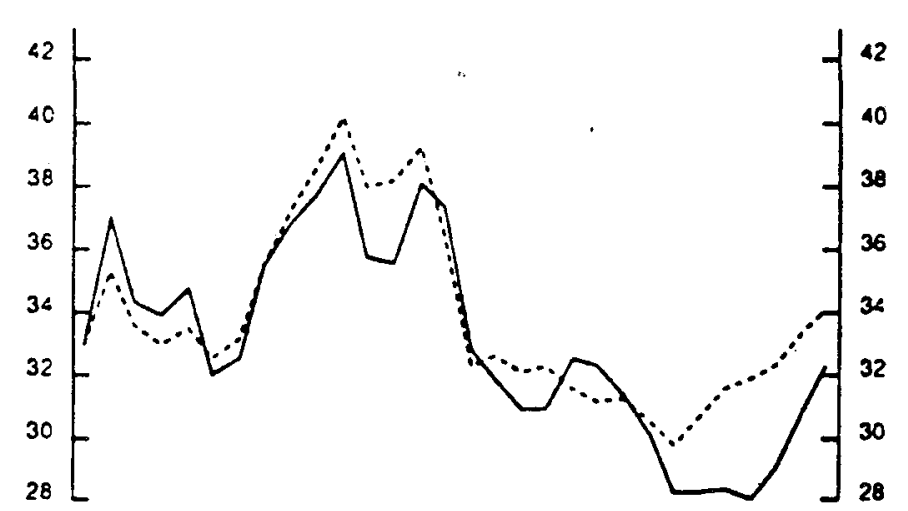

France

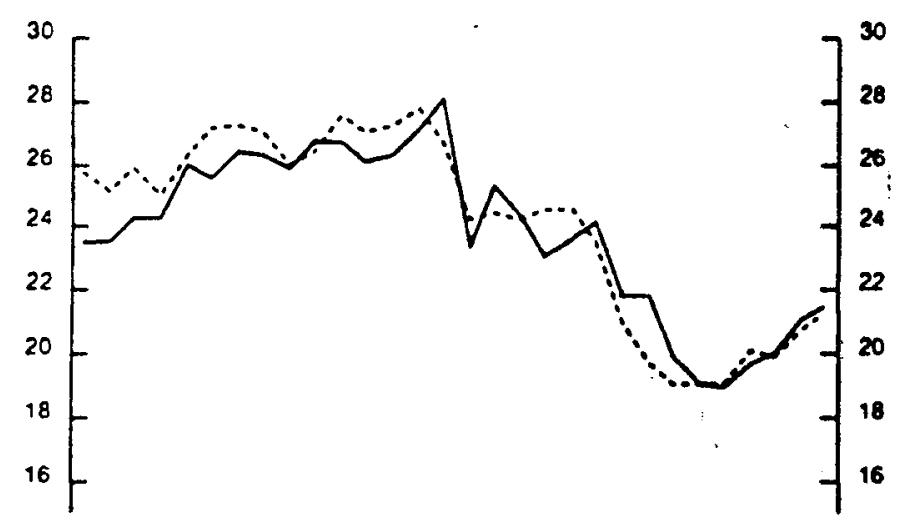

United Kingdom
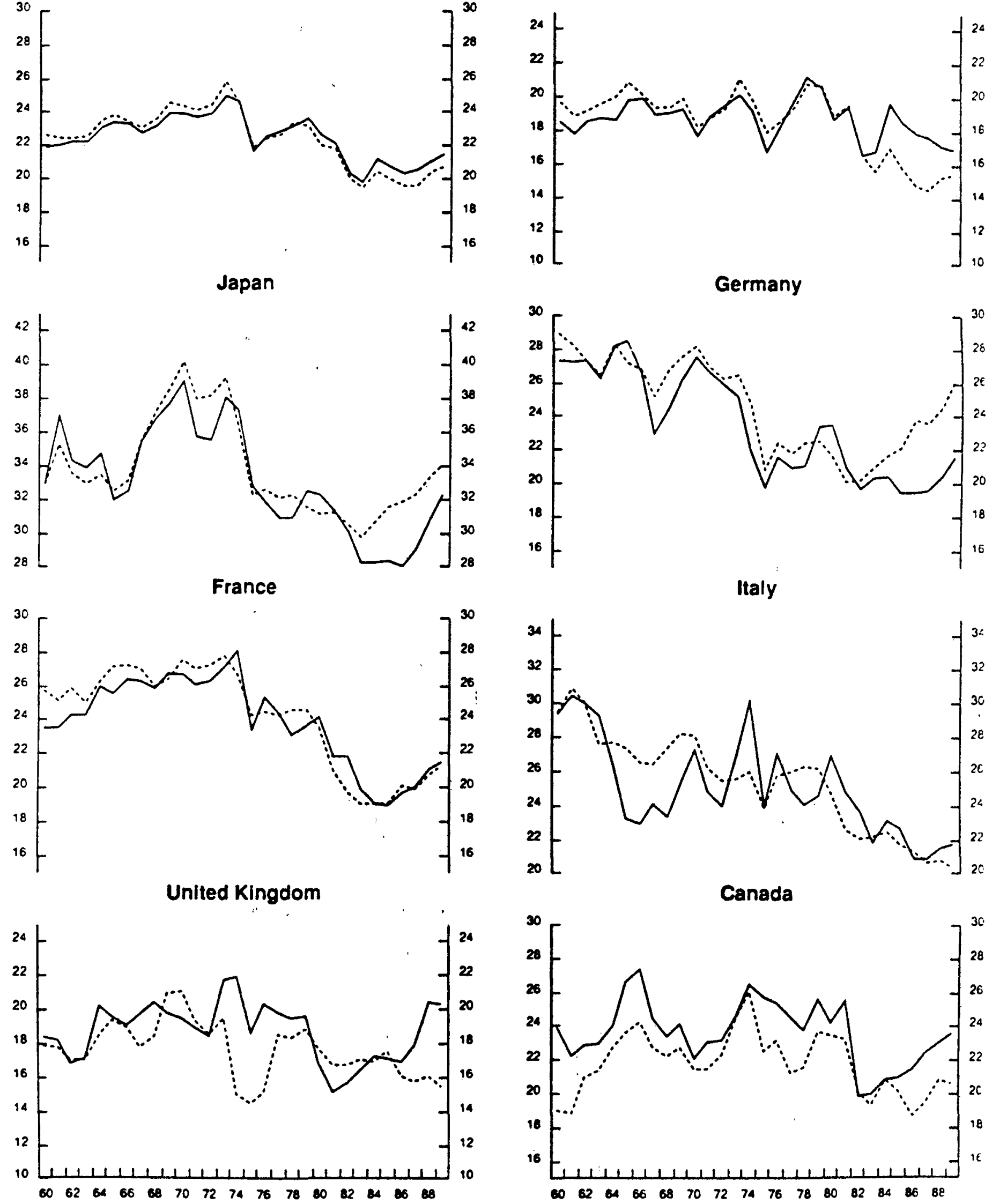

Germany

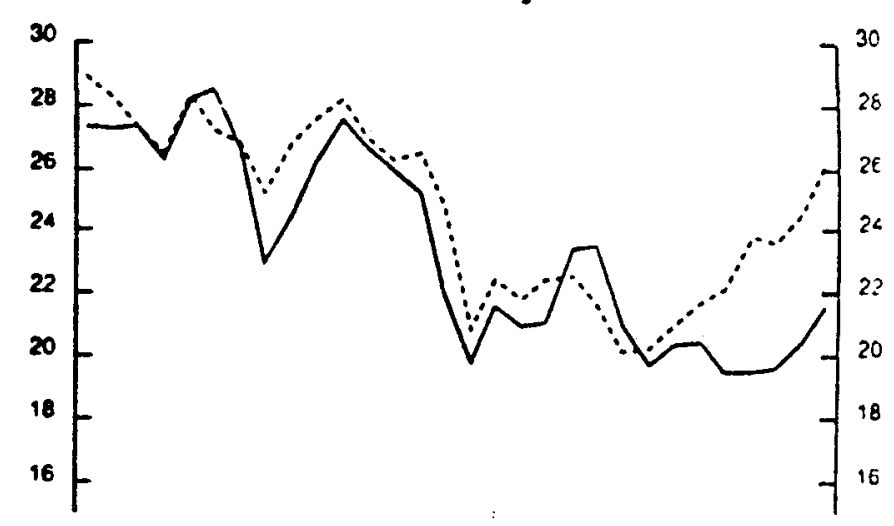

Italy

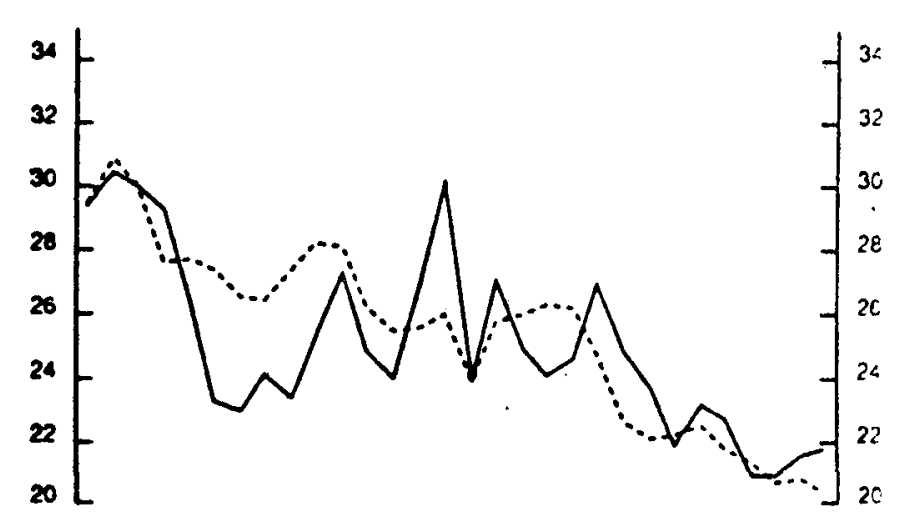

Canada

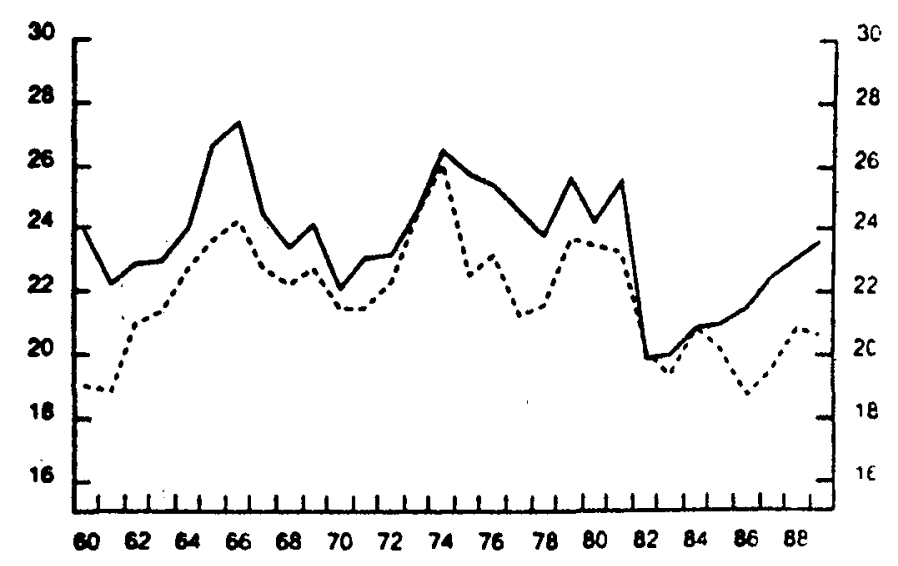

Source: OECD, National Accounts 
Total private

Public

Japan
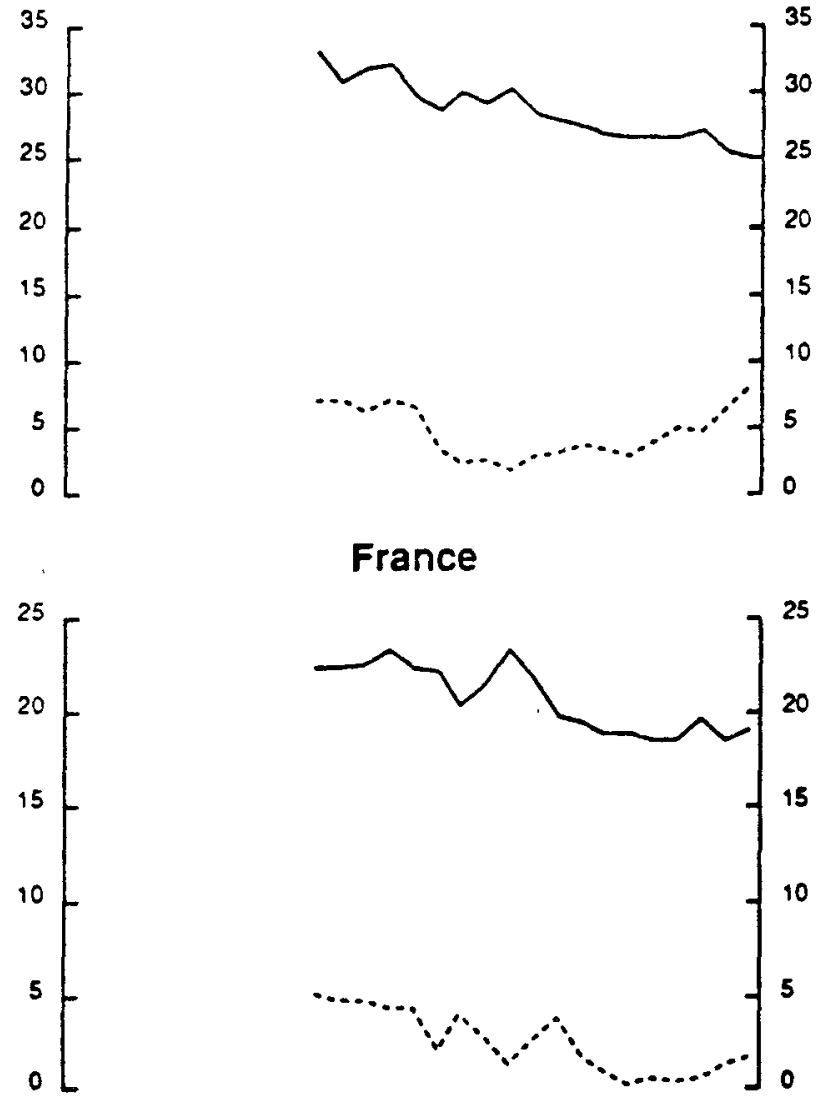

United Kingdom

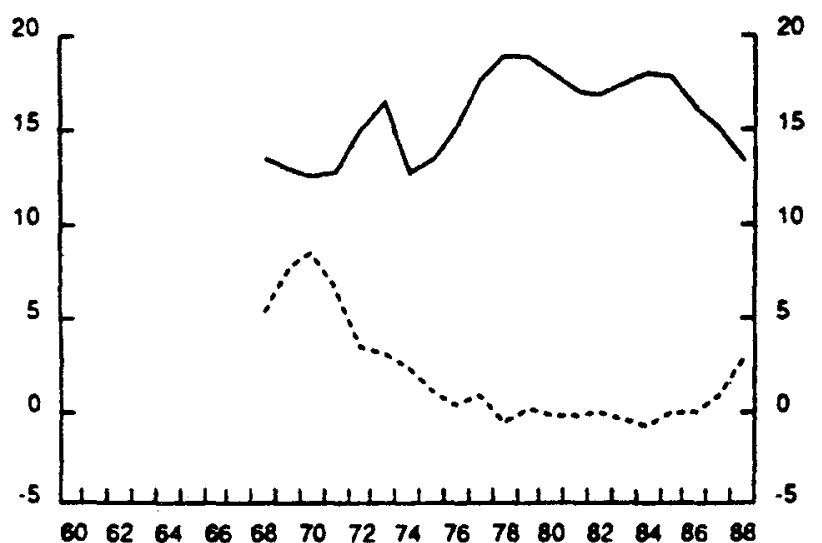

Source: OECD, National Accounts.

\section{United States}

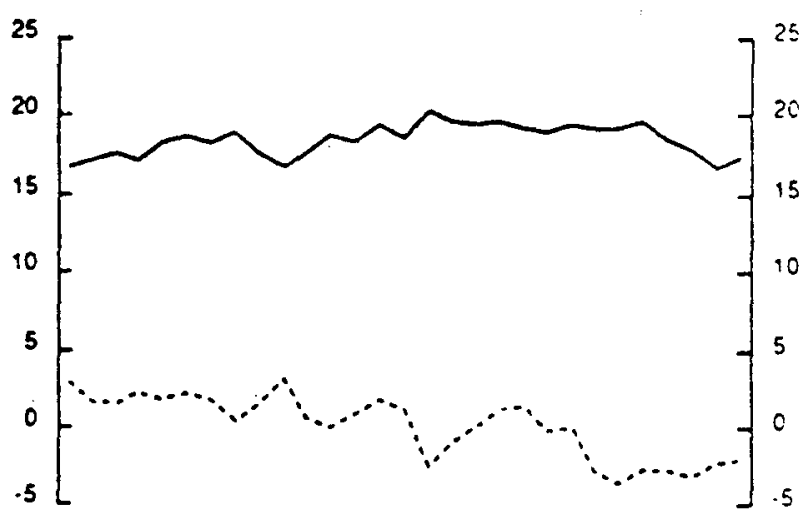

Germany

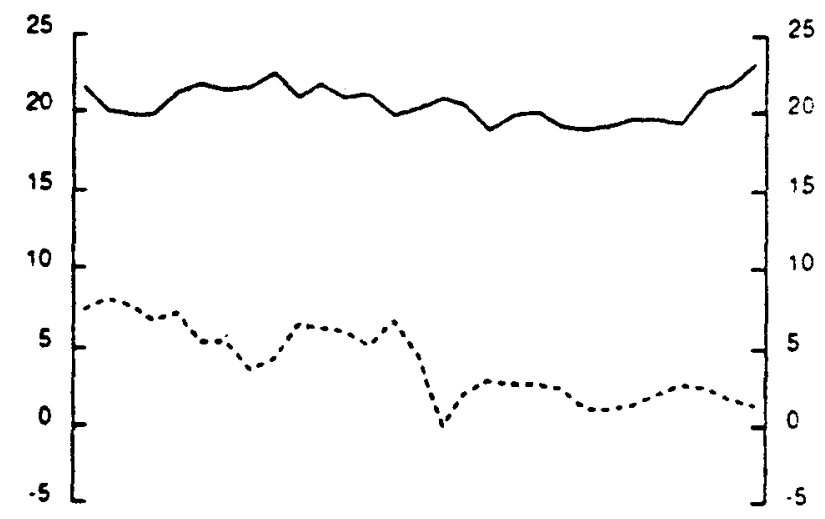

Italy
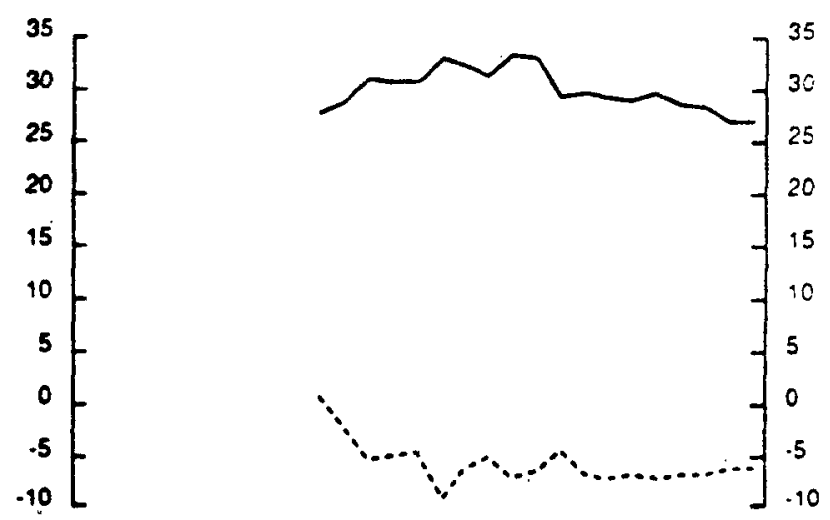

Canada

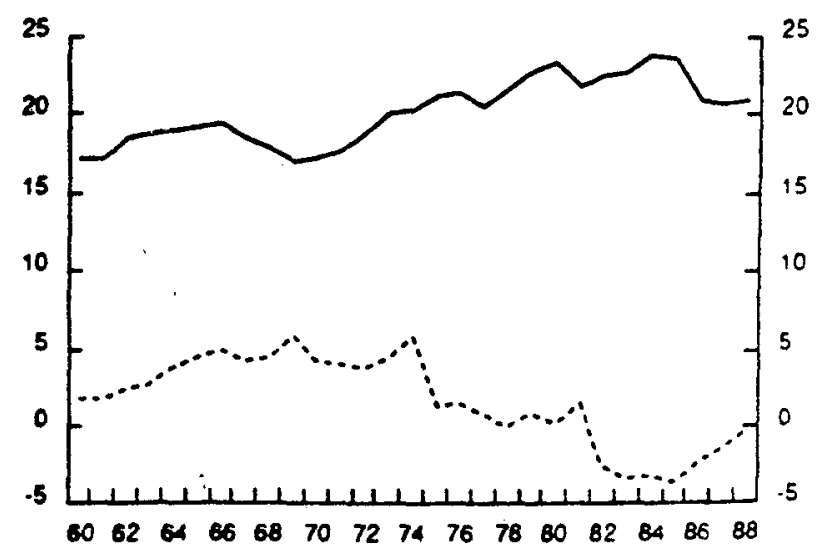




\section{Chart D}

Household and corporate saving ratios

(percentage of GNP)

Total private

Households

Corporate enterprises

Japan

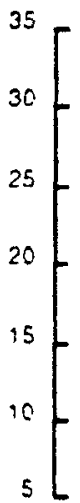

$\begin{aligned} & 24 \\ & 22 \\ & 20 \\ & 18 \\ & 18 \\ & 16 \\ & 12 \\ & 10 \\ & 8 \\ & 6 \\ & 4\end{aligned}-$

United Kingdom

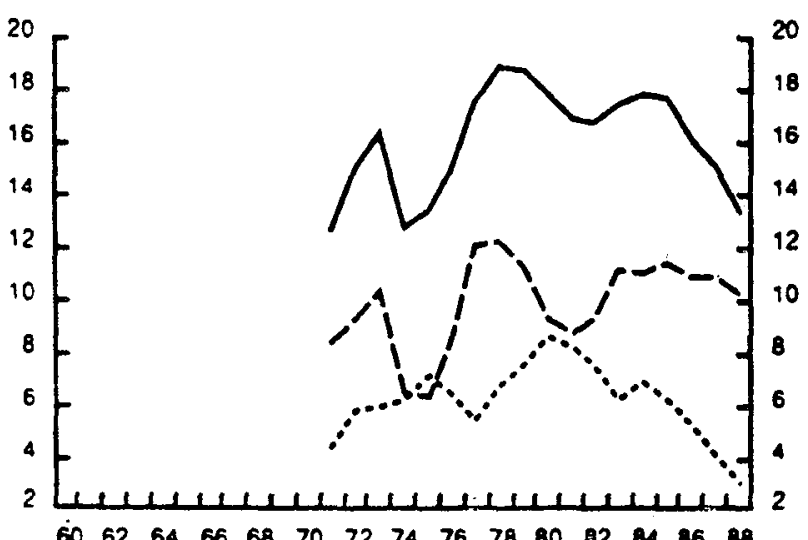

Source: OECD, National Accounts.

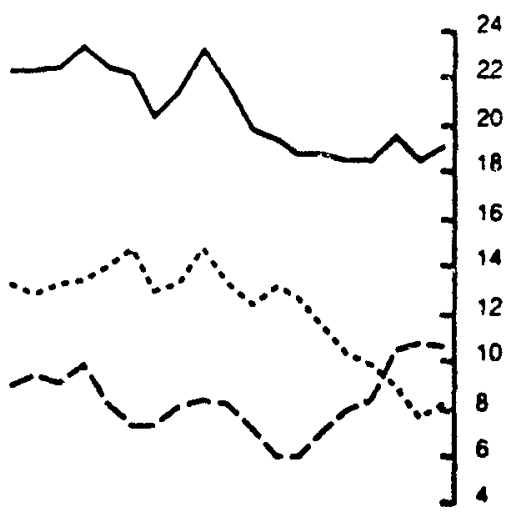

United States

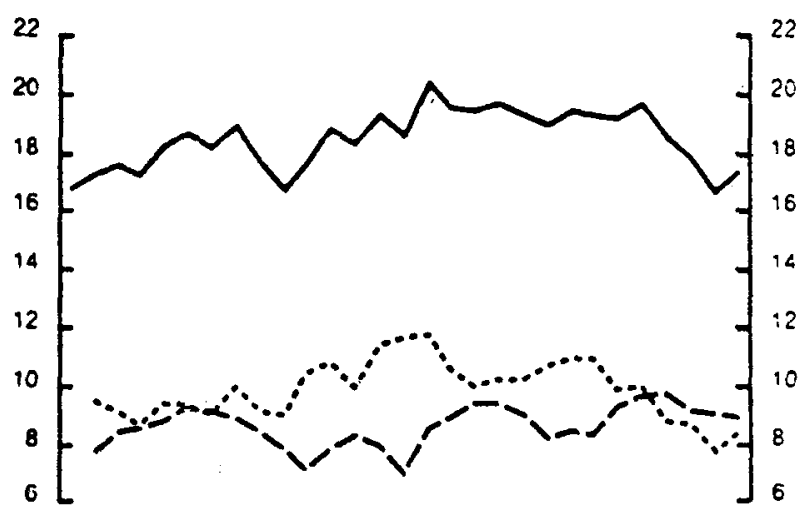

Germany

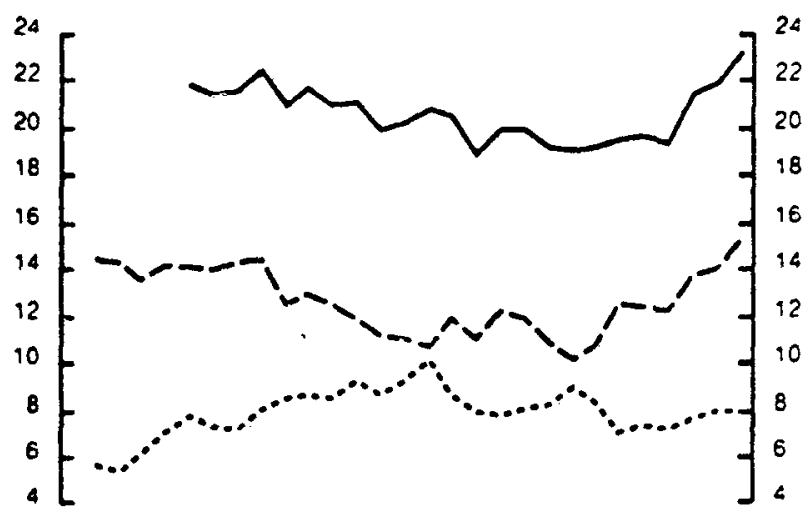

Italy
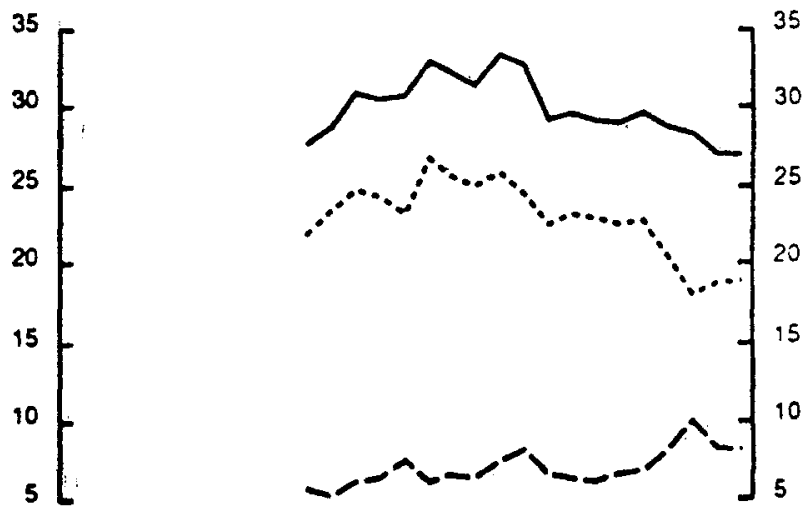

Canada

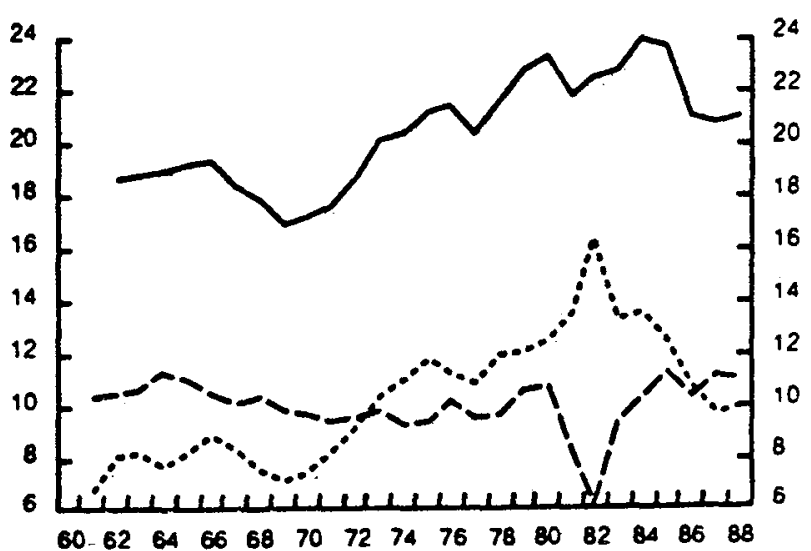


Chart E

Gross private saving ratios

(percentage of GNP)

\section{United States}

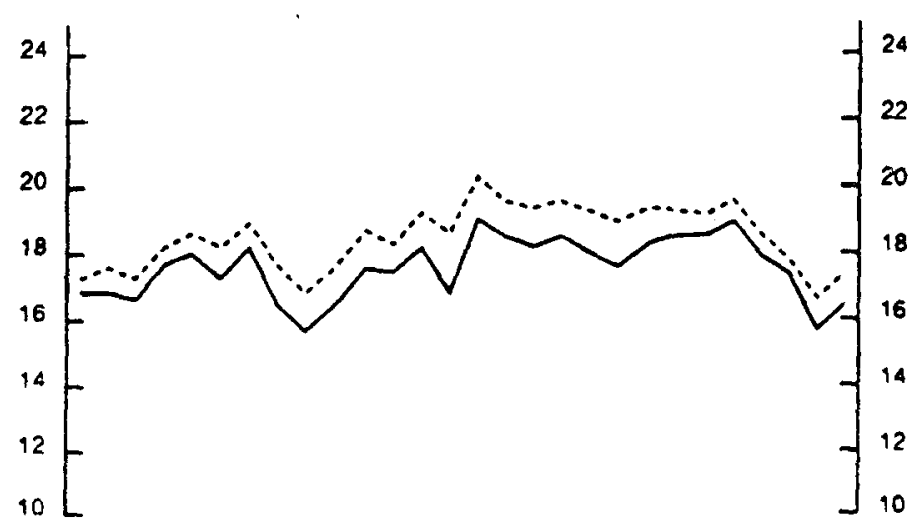

Germany
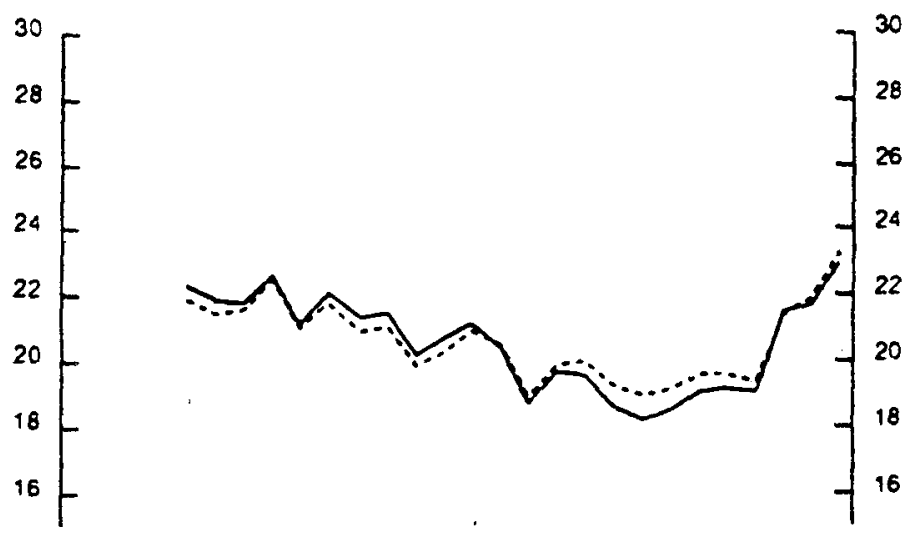

Italy
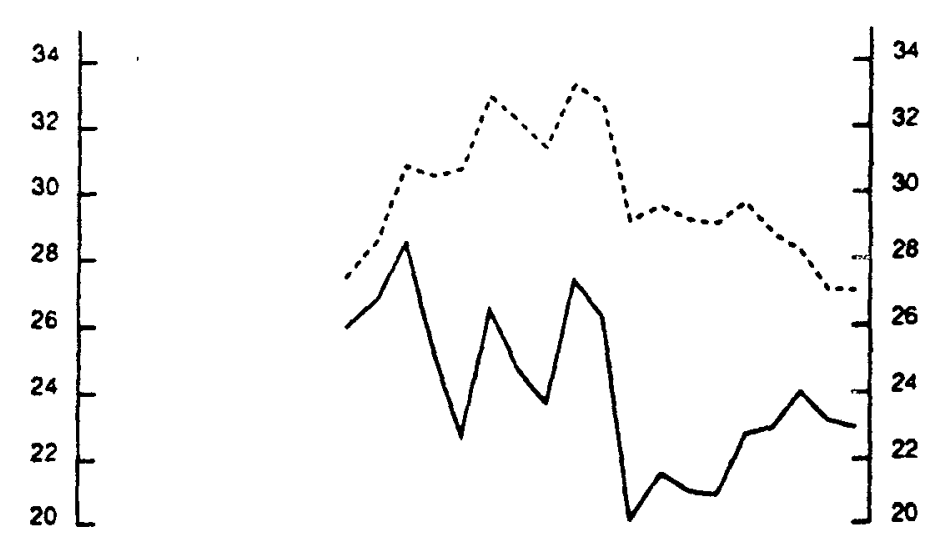

Canada

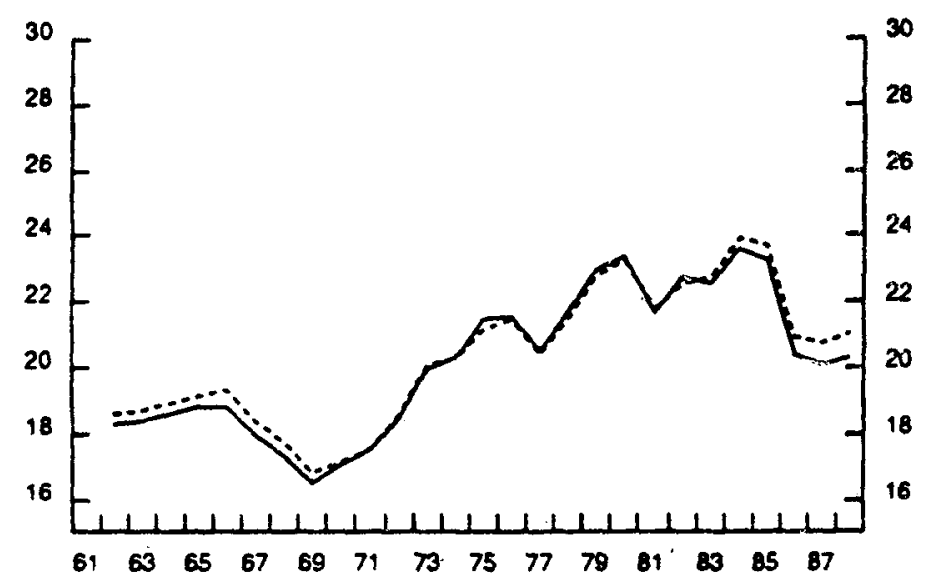

Source: OECD, National Accounts and Secretariat estirnates
Inflation adjusted

Non adjustod

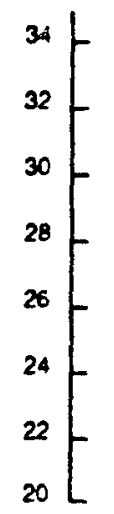

${ }_{28}^{30}$

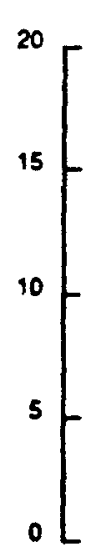

26
24
22
20
18
16
14
12
Japan

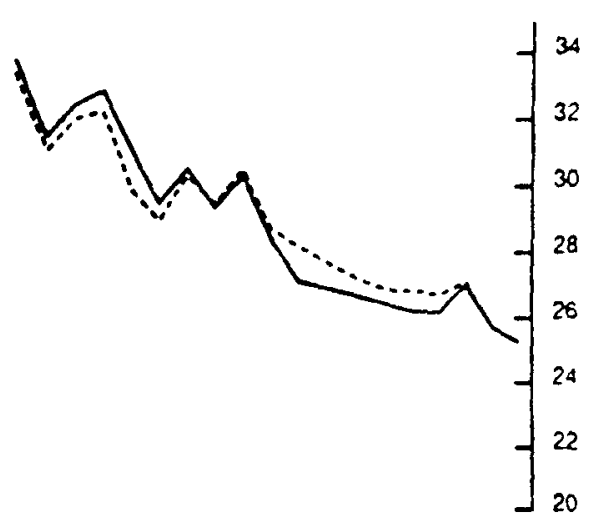

France

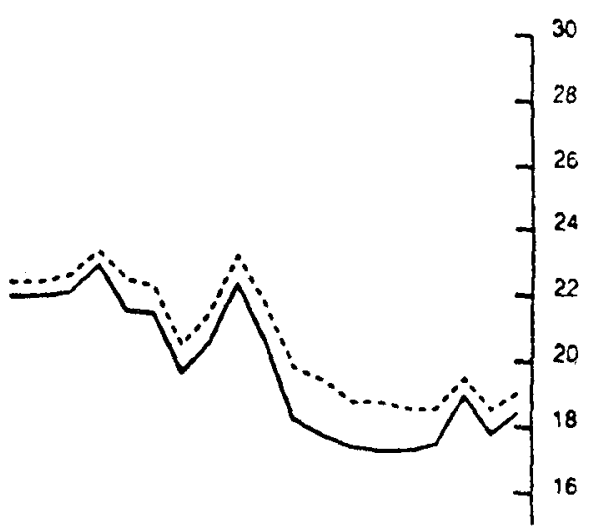

\section{United Kingdom}

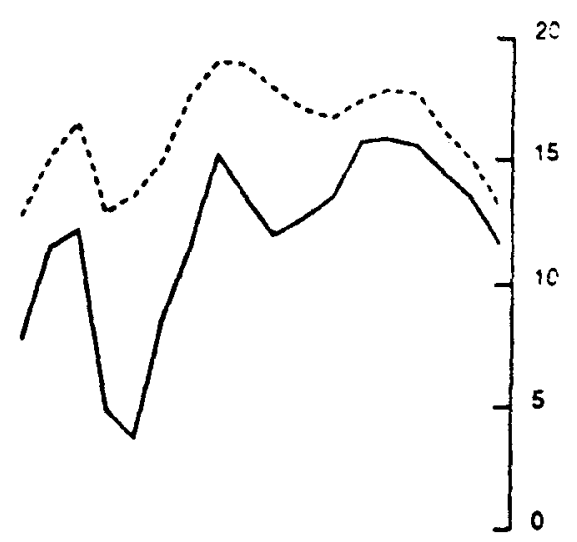

\section{Australia}

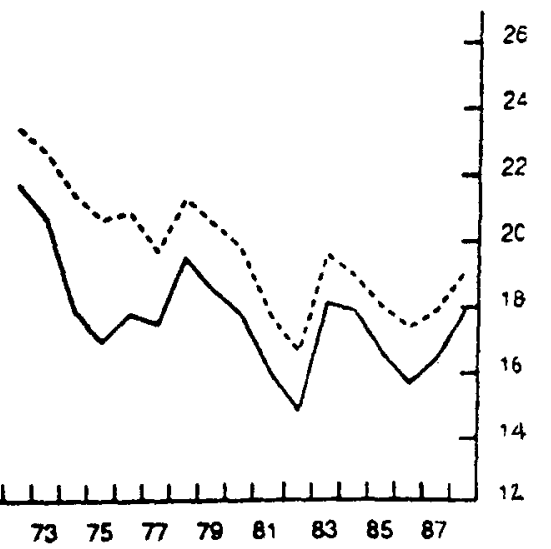


Chart E (continued)

Gross private saving ratios

(percentage of GNP)

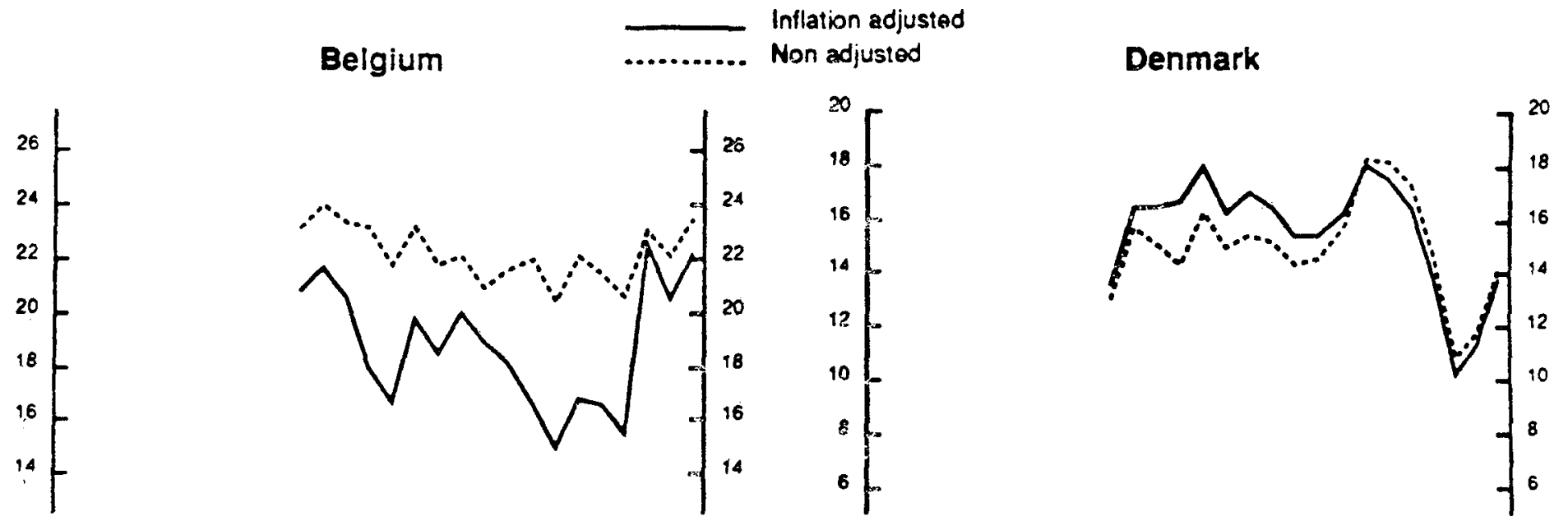

Finland

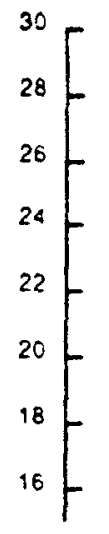

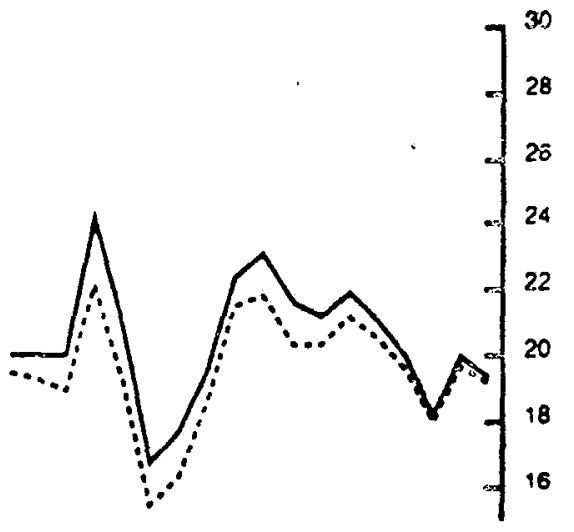

Netherlands

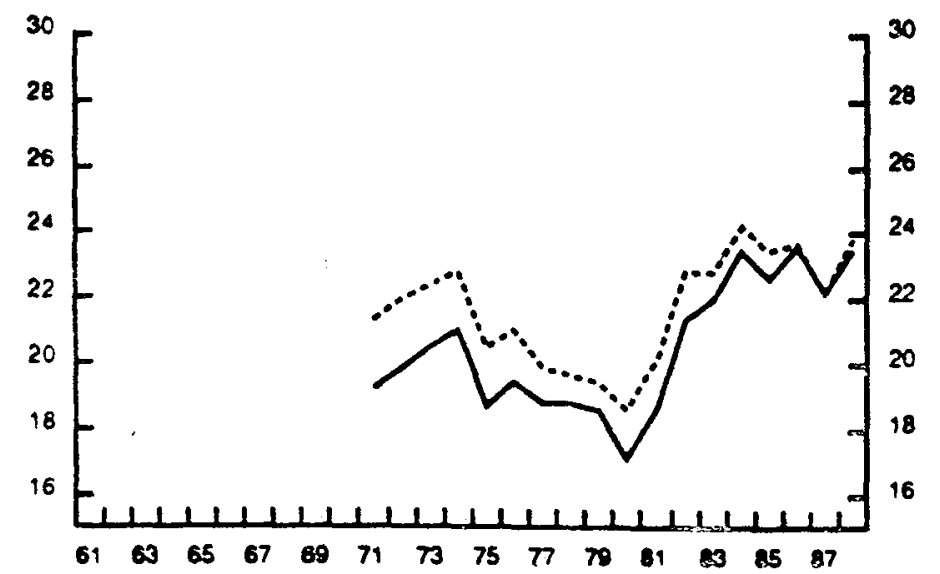

Norway

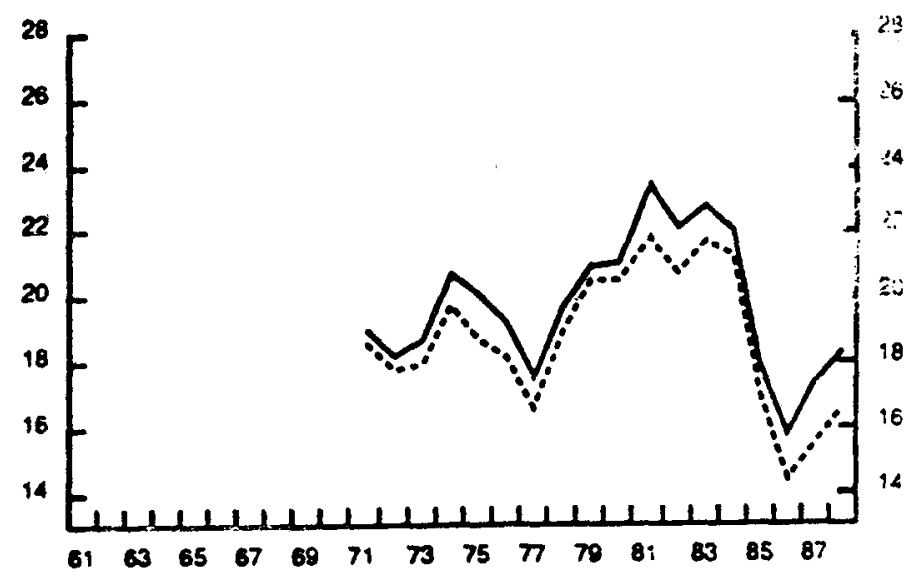

Source: OECD, National ACooumts and Sscrotariat estimates. 


\section{Bibliography}

AGHEVLI, B., J.M. BOUGHTON, P.J. MONTIEL, D. VIllaNUEVA and G. WOGLOM (1990), "The role of national saving in the world economy. Recent trends and prospects", IMF Occasional Paper, No. 67 (March).

BLADES, D. (1983), "Alternative measures of saving", OECD Occasional Studies, (June).

BLADES, D. (1989), "Revision of the system of national accounts: a note on objectives and key issues", OECD Economic Studies, No. 12.

BOSWORTH, B. (1990), "The global decline in saving: some international comparisons", Brookings Discussion Papers in International Economics, 83.

CAMBELL, J. and N.G. MANKIW (1989), "Consumption, income and interest rates: reinterpreting the time series evidence", NBER Macroeconomics Annual, MIT Press.

CULLISON, W.E. (1990), "Is saving too low in the United States", Federal Reserve bank of Richmond Economic Review.

DAVID, A. and J. SCADDING (1974), Private savings: ultrarationality, aggregation and Denison's law", Journal of Political Economy, Vo1. 82, (March-April).

DEAN, A. (1990), "World Saving since 1960: trends in saving and its global allocation". Paper prepared for the 2nd annual Villa Mondragone Conference on World Saving: Prosperity and Growth, Rome.

DEAN, A., M. DURAND, J. FALLON and P. HÖLLER (1990), "Saving trends and behaviour in OECD countries", OECD Economic Studies, No. 14.

DENISON, E. (1958), "A note on private saving", Review of Economics and Statistics No. 40 (August).

EDEY, M. and M. BRITTEN-JONES (1990) "saving and Investment" in S. Grenville (ed.) The Australian Macro-economy in the 1980s, Research Department. Reserve Bank of Australia, (June).

EISNER, R. (1988), "Extended accounts for national income and product", Journal of Economic Literature, XXVI.

EISNER, R. (1990), "The real rate of U.S. national saving", Review of Income and Wealth, $37 / 1$

FREY, B.S. and H. WECK-HANNEMAN (1984), "The hidden economy as an 'unobserved' variable", European Economic Review, 26. 
HARRIS, E.S. and C. STEINDEL (1991), "The decline in U.S. saving and its implications for economic growth", Federal Reserve Bank of New York Bulletin?

HARTWICK, J.M. (1990), "Natural resources, national accounting and economic depreciation", Journal of Public Economics, 43.

HICKS, J.R. (1946). Value and Capital, Oxford: Clarendon Press, 2nd edition.

HÖLLER, P. (1990), "Measurement issues relating to business fixed investment and capital stocks", unpublished working paper.

HILL, P. (1984), "Inflation, holding gains and saving", OECD ECOnOmiC Studies, No. 2 .

JUMP, G.V. (1980), "Interest rates, inflation expectations, and spurious elements in measured real income and saving". American Economic Review, Vol. $70 / 3$.

KOTLIKOFF, L.J. (1988), "Intergenerational transfers and saving", Journal of Economic Perspectives, No. 2, (Spring).

LAHIRI, A.K. (1989) "Dynamics of Asian saving", IMF Staff Papers, Vol. 36, No. 1, (March).

LIPSEY, R.E. and I.B. KRAVIS (1987), "Saving and economic growth: is the United States really falling behind?", Conference Board Research Report No. 901 .

MURPHY, M. (1982), "Comparative estimates of the value of household work in the United States for 1976", Review of Income and Wealth.

NICOLAISEN, J., A. DEAN and P. HÖLLER (1991), "Economics and the environment: a survey of issues and policy options". OECD Economic Studies, No. 16.

NICOLETTI, G. (1988), "A Cross-country analysis of private consumption, inflation and the 'debt neutrality hypothesis'", OECD Economic Studies, No. 11 .

OTANI, I. and D. VILLANUEVA (1988), "Determinants of long-term growth performance in developing countries", IMF Working Paper, WP/88/97, (November).

POTERBA, J. (1987), "Tax policy and corporate saving", Brookings Papers on Economic Activity, 2 .

SCHULTZE, C.L. (1988), "Setting long-run deficit reduction targets: the economics and politics of budget decisions", paper delivered to a meeting of the National Academy of Social Insurance, Washington, (December).

SOLOW, R.M. (1986), "On the intergenerational allocation of natural resources", Scandinavian Journal of Economics, $88 / 1$. 


\section{ECONOMIC AND STATISTICS DEPARTMENT \\ WORRING PAPERS}

A complete list of Working Papers is available on request.

A complete list of Working Papers No's 1-97 is available

in Working Paper No. 98.

104. GREEN - - A Multi-Region Dynamic General Equilibrium Model for Quantifying the Costs of Curbing $\mathrm{CO}_{2}$ Emissions: A Technical Manual

Jean-Marc Burniaux, John P. Martin, Giuseppe Nicoletti and

Joaquim Oliveira Martins

103. The Costs of Policies to Reduce Global Emissions of $\mathrm{CO}_{2}$ : Initial Simulation Results with GREEN

Jean-Marc Burniaux, John P. Martin, Giuseppe Nicoletti and Joaquim Oliveira Martins

102. Patterns of Recoveries for the Major Seven OECD Countries Marco Mira d'Ercole

101. P-Star as an Indicator of Inflationary Pressure

Peter Hoeller and Pierre Poret

100. Old Age Income Maintenance

Murray Petrie, Peter Sturm

99. The Measurement of Output and Factors of Production for the Business Sector in the 24 OECD Member Countries (March 91)

Mark Keese, Gerard Salou, Pete Richardson

98. Macroeconomic Consequences of Financial Liberalisation: A Summary Report (February 1991)

Adrian Blundell-Wignall and Frank Browne

97. Deregulation, Credit Rationing, Financial Fragility and Economic Performance (February 1991)

Michael Driscoll

96. Increasing Financial Market Integration, Real Exchange Rates and Macroeconomic Adjustment (February 1991)

Adrian Blundell-Wignall and Frank Browne

95. Financial Liberalisation, Asset Prices and Exchange Rates (February 1991) Marcus Miller and Paul Weller

94. Financial Liberalisation and International Trends in Stock, Corporate Bond and Foreign Exchange Market Volatilities (February, 1991)

Paul Kupiec

93. A macroeconomic model for Debt Analysis of the Latin America region and Debt Accounting models for the highly indebted countries

(February, 1991)

Peter Dittus and Paul O'Brien 
92. Unemployment Persistence and Insider-Outsider Forces in Wage Determination (February, 1991)

Bertil Holmlund

91. Infrastructure and Private-Sector Productivity (January 1991)

Robert Ford and Pierre Poret

90. The Public Sector: Issues for the 1990s (December, 1990)

Howard Oxley, Maria Maher, John P. Martin, Giuseppe Nicoletti and Patricia Alonso-Gamo

89. A Survey of Studies of the Costs of Reducing

Greenhouse Gas Emissions (December 1990)

Peter Hoeller, Andrew Dean and Jon Nicolaison

88. Business investment in the OECD economies: recent performance and some implications for policy (November 1990)

Robert Ford, Pierre Poret

87. The "PUZZLE" of wage moderation in the 1980s (November 1990)

Pierre Poret

86. Modelling wages and prices for the smaller OECD countries (October 1990)

Kenichi Kawasaki, Peter Hoeller, Pierre Poret

85. Simulating the OECD INTERLINK Model under Alternative Monetary

Policy Rules (October 1990)

Pete Richardson

84 WALRAS - A multi-sector, multi-country applied general equilibrium model for quantifying the economy-wide effects of agricultural policies : a technical manual (August 1990)

Jean-Marc Burniaux, François Delorme, Ian Lienert and John P. Martin

83 Exchange Rate Policy in Advanced Commodity-Exporting Countries:

The Case of Australia and New Zealand

Adrian Blundell-Wignall

Robert G. Gregory

82. Economies and the environment: a survey of issues and policy options (Ju1y 1990)

Jon Nicolaisen and Peter Hoeller

81. Financial liberalisation and consumption smoothing (forthcoming)

Adrian Blundell-Wignall, Frank Browne and Stefano Cavaglia

80. Fiscal indicators (April 1990)

Edward E. Gramlich, The University of Michigan

79. Suggestions for a new set of fiscal indicators (April 1990) Olivier Blanchard (MIT and NBER)

78. Indicators of fiscal policy: a re-examination (April 1990) Jean-Claude Chouraqui, Robert P. Hagemann and Nicola Sartor 